Escola de Comunicação e Artes da Universidade São Paulo

Programa de Pós-Graduação em Ciência da Informação

ELIZABETH SARDELLI MAZINI

\title{
A TRANSFERÊNCIA E A DIVULGAÇÃO DE INFORMAÇÕES DE INTERESSE MUNICIPAL
}

Dissertação de Mestrado

SÃO PAULO

2009 
A Transferência e a Divulgação de Informações de Interesse Municipal

Dissertação apresentada ao Programa de Pós-Graduação em Ciência da Informação, Área de Concentração Cultura e Informação, Linha de Pesquisa Acesso à Informação, da Escola de Comunicação e Artes da Universidade de São Paulo, como exigência parcial para obtenção do Título de Mestre em Ciências sob a orientação da Prof $^{\mathrm{a}} \mathrm{Dr}^{\mathrm{a}}$ Marilda Lopes Ginez de Lara.

\section{SÃO PAULO}

2009 
Autorizo a reprodução e divulgação total ou parcial deste trabalho, por qualquer meio convencional ou eletrônico, para fins de estudo e pesquisa, desde que citada a fonte.

Mazini, Elizabeth Sardelli

A transferência e a divulgação de informações de interesse municipal / Elisabeth Sardelli Mazini. - São Paulo, 2009.

97 p. Il.

Dissertação (Mestrado) - Escola de Comunicação e Artes / USP, 2009.

1. Informações públicas. 2. Divulgação da informação. 3. Transferência da informação. 4. Comunicação documentária. I. Título. 


\section{FOLHA DE APROVAÇÃO}

Elizabeth Sardelli Mazini

A Transferência e a Divulgação de Informações de Interesse Municipal

Dissertação apresentada ao Programa de PósGraduação em Ciência da Informação da Escola de Comunicação e Artes da Universidade de São Paulo, como exigência parcial para obtenção do Título de Mestre em Ciências.

Área de Concentração: Cultura e Informação

Linha de Pesquisa: Acesso à Informação

Aprovada em:

Presidente da Banca: Prof. Dr.

Banca Examinadora:

Prof. Dr. Instituição

Prof. Dr. Instituição

Prof. Dr. Instituição 
Ao meu pai (in memoriam) e à minha mãe, fontes de afeto e de apoio em todos os momentos.

Ao Eder, Paula, Ana Luísa e Du, fontes da minha coragem e da minha alegria. 


\section{AGRADECIMENTOS}

À minha orientadora, Prof ${ }^{a}$ Dra. Marilda Lopes Ginez de Lara, pela orientação competente, pela convivência tranquila e pela amizade.

À Prof ${ }^{\mathrm{a}}$ Dra. Ana Maria Marques Cintra e à Prof ${ }^{\mathrm{a}}$ Dra. Asa Fujino, pela contribuição durante o exame de qualificação.

À Prof ${ }^{\mathrm{a}}$ Dra. Nair Kobashi, pelo apoio no período em que fui aluna especial do Programa.

À Fundação Prefeito Faria Lima - Centro de Estudos e Pesquisas de Administração Municipal - Cepam, celeiro de muitas idéias registradas nesta dissertação, e especialmente ao Ricardo Kadouaki, pelo incentivo na fase de finalização deste trabalho.

À Fundação Escola de Sociologia e Política, especialmente à Faculdade de Biblioteconomia e Ciência da Informação, que, ao me possibilitar o exercício da docência, me trouxe para o mundo acadêmico.

À Silvia Salgado, amiga de muitas jornadas profissionais, que sempre me incentivou a realizar este trabalho e à Maria Thereza Venuzo que revisou meu texto alinhando-o com as regras da nova ortografia.

Aos colegas do Cepam que acompanharam esta minha trajetória e aos colegas da Fundação Escola de Sociologia e Política, particularmente à Liane, que me presenteou com o abstracts.

À minha família, de quem roubei muitas horas de convivência. 


\section{RESUMO}

\section{MAZINI, E. S. A transferência e a divulgação de informações de interesse} municipal. 2009. 97 p. Dissertação (Mestrado em Ciência da Informação) - Escola de Comunicação e Artes, Universidade de São Paulo, São Paulo, 2009.

Estudo sobre a transferência e a divulgação da informação no contexto dos serviços e sistemas de informação pública impulsionadas pela tecnologia. Explora, do ponto de vista teórico e prático, as interfaces estruturais, cognitivas e comunicativas que governam o processo de organização, o acesso e a transferência da informação, levando em consideração que informação é a representação de um conjunto documental que tem por finalidade a oferta e seleção de conteúdos independentemente dos suportes físicos que lhe dão materialidade. Nessa perspectiva, discute o conceito de informação, de documento e de mensagem, atentando também para os novos formatos digitais de transferência, com o intuito de verificar se funcionam como filtro perante a massa informativa disponível. Apoiando-se no referencial da Linguística Documentária, da Terminologia e da Linguística Textual, que postulam que a transferência de conteúdos semânticos para os segmentos usuários não é uma tarefa tributária da tecnologia, mas dependente da linguagem, dos propósitos da emissão, das características do público usuário e de seus conhecimentos prévios, são analisadas práticas informacionais da Fundação Prefeito Faria Lima - Cepam.

Palavras-chave: Transferência da informação. Divulgação da informação. Informação como signo. Formatos informacionais. Informação pública. Comunicação documentária. 


\begin{abstract}
S
MAZINI, E. S. The transfer and dissemination of information of municipal interest. 2009. 97 p. Dissertation (Masters in Information Science) - Escola de Comunicação e Artes, Universidade de São Paulo, São Paulo, 2009.

This study is about information transference and divulging in the context of services and systems driven by technology in the environment of public information. Both from the theoretical and practical points of view, the study also seeks to explore the structural, cognitive and communicative interfaces which govern organizational processes as well as information access and transfer, taking into account that information is the representation of documentary collections, which aims to offer and select contents independently from physical media. From this stand point, the concepts of information, documentation and message are discussed, taking into consideration the new digital transference formats with the aim of checking whether they work as a filter for the available information mass. Another objective of this study is the analysis of informational practices of Fundação Prefeito Faria Lima - Cepam - supported by the references of Documentary Linguistics, Terminology and Textual Linguistics, which postulate that the transferring of semantic contents to the user is not a technological task, but one which depends on language, emission purposes, as well as on user characteristics and previous knowledge.
\end{abstract}

Key words: Information transference. Information divulging. Informational formats. Public information. Communication documentary. 


\section{LISTA DE ILUSTRAÇÕES}

Figura 1 - Quadro-resumo do referencial teórico 25

Figura 2 - A espiral da cultura científica de Carlos Vogt. 35

Figura 3 - Códigos comuns entre emissão e recepção e processo realimentado ..... 36

Figura 4 - Representação nossa dos três paradigmas de Capurro _................................ 42

Figura 5 - Paradigma físico apresentado por Capurro \& Hjorland _........................... 43

Figura 6 - Concepção da informação por Buckland $\ldots$

Figura 7 - O esquema do CD-ROM "Estudo sobre as Pérolas de Cornalina" por Gardin

Figura 8 - Categorização como vínculo _.................................................... 76

Figura 9 - Abordagem alfabética estruturada da categorização como vínculo _....... 77

Figura 10 - Simulação de página web para P\&R 
SUMÁRIO

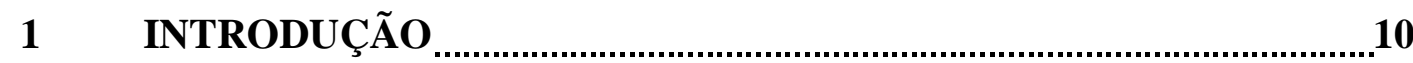

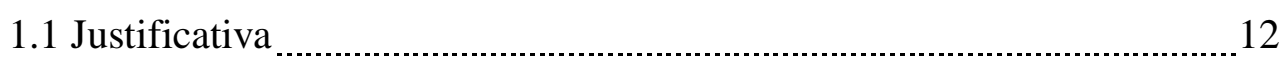

1.2 Objetivos _ _ _ _ _ $\quad 18$

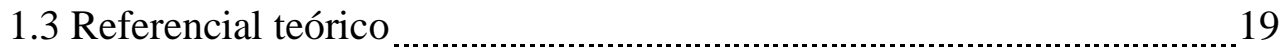

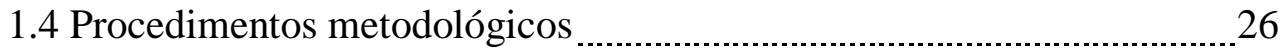

2 INFORMAÇÃO, CONHECIMENTO ESPECIALIZADO E PERCEPÇÃO PÚBLICA DA CIÊNCIA ……………………................27

3 ORGANIZAÇÃO DA INFORMAÇÃO, ACESSO E TRANSFERÊNCIA 39

3.1 Informação como coisa

3.2 Informação como signo e a Linguística documentária _.............................54

3.3 A interação com os usuários $\ldots$

4 AS EXPERIÊNCIAS PARA A TRANSFERÊNCIA DA INFORMAÇÃO DAS INSTITUIÇÕES PÚBLICAS: as práticas informacionais da Fundação Prefeito Faria Lima - Cepam ................................................... 70

4.1 A base de dados de pareceres jurídicos ……………………................... 74

$4.2 \mathrm{O}$ formato de perguntas e respostas na web

4.3 Outros meios e formatos voltados à difusão e capacitação da gestão... .85

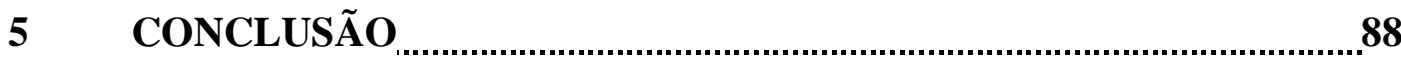

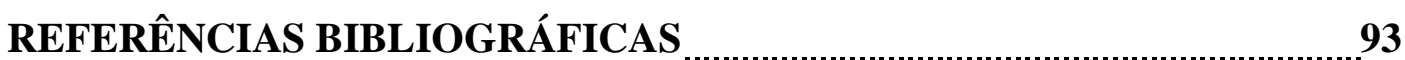




\section{INTRODUÇÃO}

conceito de informação no âmbito da Documentação está relacionado à
seleção de conteúdos de um determinado conjunto de documentos pertinentes para públicos específicos, organizados e armazenados em alguma estrutura, como, por exemplo, um sistema de informação ou um site. Produto dos procedimentos de análise documentária e, para algumas finalidades, substituta dos documentos originais, a informação documentária ${ }^{1}$ (KOBASHI, 1994) é compreendida aqui como via de acesso ou uma forma de representação que tem por finalidade a oferta de sentidos independentemente dos suportes físicos que lhes dão expressão material.

Segundo Lara (2007), a linguagem documentária é o instrumento intermediário da oferta e da seleção de sentidos. A partir de parâmetros previamente estabelecidos em nível sintático, semântico e estrutural, a linguagem documentária operacionaliza os recortes de conteúdos, significados e interpretações a serem oferecidos pelos sistemas de informação. Assim sendo, a informação no campo da Documentação é um produto cultural que integra um processo de produção fundado nos conceitos, nas normas e nos valores de uma área de conhecimento, de um campo de atividade ou de uma instituição. Em outras palavras, a informação só existe no processo comunicacional que se estabelece por meio da linguagem.

Dependente das estruturas de registro que lhe dão formato e padrão e da terminologia que referencia seu significado na linguagem documentária, a informação documentária parece ficar a mercê das instabilidades externas procedentes da área de especialidade, dos usuários, dos intermediários, da tecnologia e até dos governos em um sentido mais amplo.

\footnotetext{
${ }^{1}$ Utilizamos o conceito no sentido explorado pela autora em tese de doutorado, significando o resultado do processo documentário (resumo e metadados ou condensação e pontos de acesso temático).
} 
Se as condições de produção da informação (modos e meios disponíveis) determinam o produto, seu acesso e sua circulação, as questões a serem estudadas apontam para esse ciclo de produção e de recepção, principalmente no exame de seus aspectos estruturais, cognitivos e comunicativos, considerando o contexto tecnológico atual e as perspectivas do público usuário.

No sentido de mensagem, a informação documentária é vista além da compreensão tradicional que a define como um sinal físico, uma vez que é produto construído intencionalmente e que carrega a forma e o conteúdo definidos a partir de uma política de indexação. Em outras palavras, a informação, no sentido de mensagem, pressupõe qualificação institucional para a transferência. Somente os sentidos convergentes com a experiência do usuário têm a possibilidade de gerar novos saberes. Tal idéia impede conceber a atividade documentária considerando apenas as características físicas dos documentos. Trata-se da oferta de informações com a pretensão de auxiliar o desempenho de atividades sociais, políticas, econômicas, profissionais, artísticas, não precisando ser necessariamente fruto de uma demanda. A premissa básica é a de que os usuários, frente a uma dúvida concreta, buscam uma fonte especializada capaz de dirimir seus problemas. Na atualidade, o conceito de fonte muitas vezes ultrapassa a geografia de uma instituição, configurando, com a ajuda da tecnologia, uma instância de confluência ou ponto de encontro de várias instituições em torno da organização e distribuição de informações. Os usuários, quando necessitam de informação, interagem diretamente com essas fontes. Reconhecendo a proposta conceitual que rege a oferta, tornam-se autônomos na pesquisa, podendo encontrar com facilidade a informação capaz de responder as suas dúvidas ou, no mínimo, aprofundar suas indagações.

Tudo parece muito simples, mas no universo da informação ainda reina a dispersão. Nem sempre o usuário consegue identificar as alternativas interpretativas propostas pela fonte e, nesse caso, não chega à informação desejada. Também, nem sempre sabe a que fonte se dirigir, ficando dependente das respostas selecionadas pelos buscadores digitais. Assim sendo, defendemos a idéia de que em um mundo de ampla oferta de informação, os usuários, para manterem-se atualizados, dependem da atuação das instituições no que se refere à qualidade, atualidade, pertinência e divulgação dos 
conteúdos informacionais oferecidos, bem como da adequação da mensagem aos meios de veiculação e às condições de recepção.

Considerando a Fundação Prefeito Faria Lima - Centro de Estudos e Pesquisas de Administração Municipal - Cepam como uma fonte de informação e um canal de difusão e de divulgação que contribui para a melhoria da gestão municipal, discutimos neste trabalho algumas das práticas informacionais exercidas pela instituição, com o objetivo de ilustrar a nossa compreensão sobre os conceitos de mensagem e de transferência no âmbito da Ciência da Informação. Nosso entendimento sobre práticas informacionais coincide com o apresentado por Araújo (1999, p.155): "são ações de recepção, geração e transferência da informação que se desenvolvem em circuitos comunicacionais que ocorrem nas formações sociais". Ou seja: uma prática informacional pressupõe uma intenção e, sobretudo, a construção de um processo comunicativo entre as instâncias de produção e de recepção. O livre acesso e a ampla circulação de informações possibilitam, no circuito firmado entre as duas instâncias, um

processo dinâmico de trocas constantes, atualmente ampliados pela tecnologia. Lara (1993, 1999, 2006) e Lima (1998; 2000), denominando esse processo de comunicação documentária, esclarecem que, metodológica e operacionalmente, ele se torna possível por meio da representação viabilizada pela linguagem documentária, que, por sua vez, se referencia na Terminologia Comunicativa. Contudo, é preciso ressaltar que a mensagem que transita entre as instâncias de produção e de recepção se organiza fisicamente, constituindo-se em meio de transferência da informação (CAPURRO, 2003, p. 2 e 3). Assim sendo, os meios, nos seus diferentes formatos, também têm que ser pensados em adequação às mensagens.

\subsection{Justificativa}

Desde o final do século XX há um consenso em torno do paradigma informacional e tecnológico de que a vida no planeta é impulsionada pela informação e pela comunicação de longa distância. A literatura científica e técnica, tanto quanto a produção midiática, abordaram largamente a questão, enfocando os impactos das tecnologias nos setores econômicos, governamentais e sociais. As abordagens são diversas, contudo, no centro da reflexão geral está, a despeito do capital, o resgate do 
conhecimento, aliás, como a única forma possível de se atingir o desenvolvimento social e tornar as sociedades mais competitivas economicamente. O conhecimento, todavia, não é transmitido: o que se transfere é a informação que, em situações adequadas, pode levar ao conhecimento.

A informação e o conhecimento sempre foram essenciais ao processo de desenvolvimento, mas é a tecnologia que permite que o processamento da informação e a comunicação dos resultados desse processamento aconteçam em tempo recorde e à revelia de fronteiras espaciais. Em outras palavras, o conhecimento, na sua face material, que é a informação, torna-se um instrumento de decisão e/ou de ação sobre as coisas, considerando-se também o próprio conhecimento. É impossível qualquer decisão, tanto para a área pública como para o setor privado e organizações sociais, sem o respaldo de informações. O processamento de informações permite a análise e esclarece escolhas, projeta cenários e, assim, pode indicar acertos, evitar consequências ou aplacar impactos.

No sentido da oferta de informação, percebemos uma multiplicação de sites, portais e redes voltadas à disseminação de informações governamentais e nãogovernamentais de interesse público. É evidente a submissão do espaço real ao tempo virtual, modificando a relação da humanidade com a informação. "O habitante do tempo, e não mais do espaço, [...] é o destinatário de completas informações sobre o acontecido a cada instante" (REALE JR., 2008). A rapidez da comunicação e a facilidade de interação com várias fontes de informação promovem o consumo da novidade e, ao mesmo tempo, sua rápida obsolescência. A visibilidade e a capacidade de informar passam a ser a condição de permanência das fontes e, nesse regime, o ato de informar, submetido a um ritmo frenético, pode perder o tempo da reflexão, ou seja, o tempo da análise e do processamento sobre o que de fato tem valor informativo e para quem.

No contexto dos serviços e sistemas de informação pública, impulsionados pelas novas tecnologias, o que está sendo demandado é a transformação das informações em valores práticos, destinados ao uso presente. Para isto, os acervos ou estoques de informação têm de ser dinamizados e reestruturados para oferecer produtos informativos 
acessíveis a distância por meio de canais e meios diversos. A gênese da organização de informações está no processo comunicacional, no vínculo estabelecido com o usuário e com outros sistemas e fontes de informação. Sua importância deslocou-se do registro para o mundo das relações e, assim, uma mesma informação pode aparecer em diferentes formatos, ser divulgada por diferentes canais ou compor várias redes, justificada pelo seu potencial valor de uso e de troca. Tudo isso aumenta a oferta, a visibilidade institucional e as possibilidades de acesso. Contudo, a ausência de políticas que imponham racionalidade e equilíbrio aos universos de produção e de recepção, abrangendo as etapas de organização, armazenamento, distribuição e consumo, tem trazido bastante dificuldade, se não para o setor de produção, com certeza para os usuários, pois a recuperação de informação diante da massa disponível torna-se uma operação complexa.

De acordo com a literatura da área de Ciência da Informação, o processo de produção de informações não trata apenas da disponibilização, mas da intelegibilidade dos produtos oferecidos, com o objetivo de conquistar maior eficácia junto aos usuários. A informação de cunho técnico-científico, entendida como valor semântico expresso por meio de um formato linguístico, não deve sofrer alteração em função dos diferentes suportes ou meios que a transportam. Contudo, em nome de possibilitar acesso, muitas vezes, produtos de qualidade misturam-se a outros promovendo desinformação.

No mundo da informação, baratear a produção pode significar comprometer a recepção, ou seja, como a informação é passível de interpretações, segundo Lara (1999), seu entendimento deve estar referenciado em escolhas institucionais seguras, pautadas no domínio temático e em garantias de uso. Assim sendo, segundo a autora, tornar as dimensões simbólicas, adotadas na organização, evidentes e acessíveis pode facilitar a operação de seleção a cargo do receptor e diminuir as falsas recuperações.

Nos sites do setor público, dois recursos são muito adotados para suprir as dificuldades de localização da informação desejada: a possibilidade da busca livre e a edição de notícias e manuais. Contudo, esses recursos por si só não são suficientes. A busca livre, por operar em linguagem natural, apresenta alta polissemia e nem sempre nos conduz com agilidade a um resultado pertinente. As notícias são voláteis, entram e 
saem do primeiro plano do site e a recuperação de informações acumuladas e dispersas nos diversos artigos só se torna possível ou pelos buscadores ou pela organização em diretórios temáticos. Quanto aos manuais e guias, a linguagem adotada e a organização do texto nem sempre favorecem a informatividade ${ }^{2}$, comprometendo a orientação que se pretende transmitir ao leitor. Algumas vezes excede, outras vezes abrevia demais as explicações. A idéia de que um manual é um texto orientador, estruturado para ter legibilidade e inteligibilidade junto a públicos específicos, pode melhorar o quadro de oferta.

Hoje, no âmbito da web, em contrapartida ao valor informativo dos recursos veiculados, desenvolve-se uma competição entre sites por número de acessos. Existe uma série de ferramentas cujo propósito é quantitativo, quero dizer, são ferramentas estratégicas que servem para atrair consultas a um site, elevando o número de acessos. O Google analitics, por exemplo, pode funcionar nessas condições. A partir da construção de uma ampla lista de palavras-chave, representando as diversas possibilidades de busca de uma página web (sinônimos, plural, orações, palavras, termos, verbos, etc.), usuários potenciais são conduzidos ou estimulados a usar os sites. Outro serviço oferecido é o RSS (Rich Site Summary ou Really Simple Syndication), que se assemelha aos serviços de disseminação seletiva da informação, isto é, permite aos usuários da internet inscreverem-se em sites que fornecem fontes (feeds) RSS. Utilizando o recurso, o usuário pode permanecer informado sobre as atualizações processadas em diversos sites sem precisar visitá-los, cotidianamente, um a um. Todavia, do ponto de vista da pesquisa na área de informação, esse recurso só representa um avanço se a fonte for reconhecida pelo usuário como segura. Isso mostra que a informação é uma questão institucional e não tecnológica. $\mathrm{O}$ recurso responde bem porque as fontes são confiáveis.

\footnotetext{
${ }^{2}$ Segundo Ortega e Lara, 2009, p. 529, a informatividade é a possibilidade de um documento tornar-se informativo. Mais do que a informação, é a informatividade que permite entrever o jogo intertextual que caracteriza os processos de recepção, determinando os critérios de relevância para que algo seja considerado informativo. A capacidade de um documento ser informativo enfatiza o aspecto pragmático do objeto informacional, à medida que revela $\mathrm{o}$ caráter social e simbólico da informação e, consequentemente, os ambientes e as situações concretas de uso.
} 
Nesse contexto de oferta abundante de informação, o enfoque que privilegiamos é o comunicacional, pois compreendemos que a informação, para interferir na realidade, demanda mais do que acesso, demanda, isto sim, laços com a comunidade usuária. Do nosso ponto de vista, a viabilidade da formação/manutenção de bibliotecas, bases de dados, sistemas, redes e portais (unidades fundamentais à geração do conhecimento) está na função de transferência e de uso de informação, pressupondo a qualidade e pertinência da oferta.

Com base na argumentação de que a informação é "algo" distinto do conceito de documento, próximo da noção de mensagem, que se distancia da noção de registro para privilegiar os fluxos informativos que atinjam segmentos específicos de usuários, exploramos os conceitos de informação como signo e de informação como objeto.

Atentamos também para a espiral da cultura científica sistematizada por Vogt (2003, 2005), que demonstra que as informações especializadas, para atingirem o conjunto da sociedade, são processadas em circuitos específicos, ao mesmo tempo em que são divulgadas amplamente. $\mathrm{O}$ autor considera que o interesse social pela informação científica envolve uma mudança cultural e, para isso, relaciona a atuação de meios de comunicação diversos, tanto quanto de canais formais e informais. Com olhar voltado para os circuitos específicos, observamos também as perspectivas de Gardin (2001) sobre a modelagem das publicações científicas que fazem referência à filtragem de informações e sua organização em novos formatos de difusão (mais orientados para a consulta), com vistas a diminuir o impacto da massa informativa disponível frente ao tempo despendido para essa assimilação.

Em resumo, com foco na informação como mensagem, investigamos como as instituições públicas vêm focando o processamento informacional para a otimização da circulação do conhecimento, a difusão dos estoques e o controle da desinformação. A distinção entre os processos de produção e transferência da informação, dependentes da linguagem, e a escolha dos meios adequados a cada aplicação são considerados fatores fundamentais para que a informação não seja compreendida como sinônimo de tecnologia. Procuramos esclarecer que a complexidade em torno da produção e da recepção de informações não se resolve apenas com acesso tecnológico. Para que a 
informação seja efetivamente percebida e consumida socialmente, ela precisa estar associada a ações que minimizem ou solucionem diferenças sociais, culturais, educacionais e econômicas que dificultam a sua apreensão e uso, como também a inclusão digital propriamente dita.

Para se inserir no regime de informação vigente (GONZÁLEZ DE GÓMEZ, 2002) ${ }^{3}$, que pressupõe a possibilidade de comunicação a distância, o Cepam compatibiliza sua ação informacional ao uso das tecnologias. Tal iniciativa, que objetiva a disponibilização de informações por meio da internet, é dotada de grande complexidade, pois, para que a demanda possa reconhecer os atributos de qualidade, utilidade e pertinência da informação oferecida, esta tem que continuar aportando sentidos compreensíveis, isto é, vinculados ao contexto dos sujeitos receptores.

$\mathrm{Na}$ área abordada por este trabalho, a percepção que se tem é a de que os meios usuais de difusão e de transferência de conhecimento/informação referem-se à constituição de repositórios em portais governamentais, observatórios, sites de programas de pós-graduação, de especialistas renomados, e a edição de revistas e de publicações em formato digital. Desprendendo-se da formação de estoques do tipo Bibliotecas e Centros de Documentação, reconhece-se, nas aplicações, mais uma seleção e/ou um arranjo documental em formação, com objetivo de comunicação técnico-científica, do que uma preocupação com o processamento e o armazenamento para uso futuro. Argumenta-se que essas configurações (modernas), principalmente os observatórios e as bibliotecas digitais e virtuais, são empreendimentos dirigidos à difusão, distribuição e ao consumo da informação. A biblioteca virtual do Governo estadual paulista filtra conteúdos de outras unidades informacionais, reescreve e redistribui pensando no público amplo, não só nos setores governamentais. Os

\footnotetext{
${ }^{3}$ Segundo a autora, regime de informação é "um modo de produção informacional dominante em uma formação social, conforme o qual serão definidos sujeitos, instituições, regras e autoridades informacionais, os meios e os recursos preferenciais de informação, os padrões de excelência e os arranjos organizacionais de seu processamento seletivo, seus dispositivos de preservação e distribuição. Um 'regime de informação' constituiria, logo, um conjunto mais ou menos estável de redes sociocomunicacionais formais e informais, nas quais informações podem ser geradas, organizadas e transferidas de diferentes produtores, através de muitos e diversos meios, canais e organizações, a diferentes destinatários ou receptores, sejam estes usuários específicos ou públicos amplos".
} 
observatórios realizam uma filtragem mais dirigida aos campos especializados. Na área de políticas públicas eles se propõem a acompanhar programas específicos de governo ou os avanços dentro de temáticas ou setor de atividade. Eles divulgam dados objetivos de acompanhamento e de avaliação das políticas, como, por exemplo, resultados de pesquisas, experiências relevantes nacionais e internacionais, literatura técnicocientífica sobre o assunto, legislação relacionada, informações econômicas, estatísticas, notícias de eventos, opinião de especialistas, etc. Os observatórios, em nossa opinião, fazem a travessia dos centros de informação especializados para a era digital. São menos comprometidos com a memória e/ou armazenamento e mais com a articulação e difusão de informações e de produtos provenientes de fontes diversas, embora considerem essencial que os registros sejam elaborados e gerenciados. Os observatórios, na sua face externa, estão voltados para a divulgação e/ou distribuição da informação, mas, quando pensamos na sua face interna, como qualquer outro sistema, depende de processamento, de formas de armazenamento, de gestão e de política de informação. Também, na sua maioria, eles não deixam de ter uma interface ativa com os usuários, não só para contato como também para troca, isto é, para coleta sistemática de dados e informações sobre os temas, políticas e experiências acompanhadas.

Esse quadro bastante influenciado pelas possibilidades tecnológicas propõe indagações: As práticas informacionais desenvolvidas na implementação desses meios encampam as desenvolvidas pelos sistemas documentários? Como se caracterizam as ações de informação dirigidas para a divulgação do conhecimento técnico-político? A tecnologia, entendida como meio de produção, interfere nessas práticas? Como se situa o Cepam nesse contexto? Como desenvolve os processos informativos para responder a demanda dos municípios e divulgar conhecimentos de interesse da gestão municipal?

\subsection{Objetivos}

\subsubsection{Objetivo geral}

Como objetivo geral, pretendemos investigar requisitos gerais de organização, armazenagem e difusão frente ao paradigma tecnológico-informacional vigente e os padrões de qualidade, continuidade e pertinência da informação. 
Frente a essas referências, procuraremos verificar o desempenho da Fundação Prefeito Faria Lima - Cepam e avaliar suas contribuições para o estabelecimento da comunicação documentária generalizáveis para outras instituições governamentais semelhantes.

\subsubsection{Objetivos específicos}

Como objetivos específicos, pretendemos identificar o processo de organização, acesso e transferência de informações, no exame de seus aspectos estruturais, cognitivos e comunicativos, considerando as principais abordagens que se constituem em paradigma, os instrumentos necessários, os meios e agentes envolvidos em cada processo.

Nessa análise, procuraremos considerar as novas perspectivas de organização e transferência da informação técnico-científica que fazem referência à elaboração e manipulação de formatos digitais e os respectivos contextos de uso, bem como verificar a função e os limites da informação documentária no processo de transmissão e circulação do conhecimento, identificando os principais campos de estudos subsidiários dessa operação.

\subsection{Referencial teórico}

As respostas às indagações e aos objetivos apresentados são elaboradas por meio do desenvolvimento de três capítulos, excetuando-se esta apresentação.

O capítulo 2, "Informação, conhecimento especializado e percepção pública da ciência", faz a distinção entre os conceitos com base no trabalho dos pesquisadores Aldo Barreto (1994, 2002), Nair Kobashi (1994, 2003) e Fátima Tálamo (2003), para os quais a informação é uma construção significante, podendo, segundo os autores, constituir-se em bem público ou mercadoria conforme os propósitos da fonte produtora. Nessa mesma linha, acrescentamos as contribuições de Rafael Capurro (2002), que define informação como oferta e seleção de sentidos, algo que depende da transmissão de sinais, de mensagens, de interpretação e de conhecimento prévio. Também, contribui 
para o desenvolvimento deste capítulo a pesquisa de Carlos Vogt (2003, 2005), que demonstra, por meio do modelo "o espiral da cultura científica", os percursos trilhados pela comunicação científica na sociedade. A pretensão é mostrar que a comunicação científica entre pares e a percepção social da ciência, assim como o processo documentário, são tributários da linguagem, sem a qual a memória, o conhecimento e o reuso da informação se tornam operações impossíveis. Referimo-nos, ainda, às análises de Manuel Castells (1999) sobre a sociedade da informação e às contribuições de Boaventura Santos (1989) sobre a mudança de paradigma no campo científico, impactando todas as disciplinas e, consequentemente, a Ciência da Informação.

O capítulo 3, intitulado "A organização da informação, acesso e transferência", procura apresentar a evolução da disciplina Ciência da Informação, seus antecedentes e marcos epistemológicos fundamentais, na visão de Rafael Capurro (2003), nomeados de paradigma físico, paradigma cognitivo e paradigma social/pragmático. O cerne do capítulo está na discussão do conceito de informação e no seu relacionamento com outros conceitos importantes da Ciência da Informação, tais como os conceitos de documento e de conhecimento. Observada como processo objetivo, a informação é algo dependente do relacionamento sistêmico entre emissão e recepção (codificação e decodificação), entretanto, do ponto de vista subjetivo, equipara-se à situação de signo, "algo" passível de interpretação por seres sociais pensantes e culturalmente determinados. O que entra em jogo é a relatividade do valor informativo daquilo que consideramos informação, relacionado que é ao uso e às trocas simbólicas.

$\mathrm{Na}$ primeira abordagem são referenciados diversos teóricos, iniciando-se a discussão por Paul Otlet (1934), para quem o conceito de documento ultrapassa o limite de sua constituição física ou de obra impressa. Seguem-se a ele observações na mesma linha, de Suazane Briet (1951), de Merriat (1981), de Capurro (2003), de Rodríguez Bravo (2002) e Ortega e Lara (2008, 2009), sendo que o ponto focal do item é a proposição de Buckland (1991, 1997), que diz que qualquer coisa pode ser informativa. O autor argumenta que a informação está por toda parte (o mundo é feito dela) e divide o conceito em: "Informação como coisa", "Informação como conhecimento" e "Informação como processo". Situa o campo da Ciência da Informação entre os objetos e os processos tangíveis de significação/re-significação de conteúdos que propiciam a 
circulação do conhecimento e a constituição de novas informações, sejam elas coisas ou documentos.

$\mathrm{Na}$ abordagem da informação como signo são exploradas as contribuições da Linguística à Ciência da Informação, particularmente os estudos de Maria de Fátima Tálamo (1992, 1997, 2001, 2003, 2007) e Marilda L. G. de Lara (1993, 1999, 2006, 2007) sobre a disciplina Linguística Documentária e sua interface com a Terminologia que estuda a linguagem documentária, no seu aspecto processual e instrumental.

A abordagem permite a concepção da informação documentária como uma estrutura significante (signo documentário), próxima à noção de mensagem, pois, conforme diz Capurro (2003, p. 2 e 3), "só a mensagem pode ser transmitida, a informação não". Inserida no marco teórico social-pragmático da Ciência da Informação, a abordagem considera que as instâncias de produção e recepção da informação são habitadas por sujeitos dinâmicos comprometidos com uma realidade cultural e social definida, e, nesse sentido, a informação só pode ser compreendida mediante o seu compartilhamento com o segmento usuário destinado. Em estado de armazenamento, fora do processo informacional que a qualifica para uso e circulação em contextos específicos, é recurso informacional, um documento ou coisa, mas ainda não é informação. Compreendemos que a informação é o "o ponto de vista adotado para analisar os processos e os objetos do mundo", ou seja, a informação é uma unidade intelectual decorrente de uma "atribuição de sentido" que, fisicamente, se representa através da emissão de documentos (TÁLAMO e SMIT, 2007, p. 1). Sobre o conceito de documento, Ortega e Lara (2008, p. 4) esclarecem: "funcionalmente o documento conserva dados (aspecto estático) e ao mesmo tempo informa. Estruturalmente, o documento é container e difusor, assim como é forma e substância”.

Nesse contexto, documento e informação são objetos diferentes se observados de per si, mas indissociáveis na perspectiva social e global do processo informativo, que tem por finalidade transformar os estoques documentários (aspectos estáticos) em fluxos de informação passíveis de uso (mensagens). Tal operação é viabilizada por meio da codificação/decodificação dos conteúdos informativos mediados pela linguagem documentária. A função da Linguagem Documentária no processamento da informação 
é garantir significação ao conjunto vocabular produzido, isto é, garantir normalização e estabilidade às suas unidades constituintes para representarem um determinado aspecto da realidade (contexto comunicativo), uma vez que a linguagem natural promove a dispersão da informação. Entendida como o elo simbólico que relaciona conteúdos informacionais com sujeitos reais, isto é, com pessoas portadoras de necessidades de informações e de saberes específicos, as linguagens documentárias, segundo Lara (2006), têm que ser respaldadas nas terminologias.

Assim sendo, o item "Informação como signo" está referenciado na Teoria Comunicativa da Terminologia (TCT), proposta por Cabré (1999), pois, segundo Lara (2006), é a que mais se adapta às operações documentárias porque, ao considerar a dimensão textual e discursiva, entende os termos

como unidades denominativo-conceptuais que têm capacidade de referência desde que ativados em seu uso em contextos e situações determinados. Quando ativados, os conceitos de um mesmo âmbito especializado mantêm entre si relações que constituem a estrutura conceptual do campo de assunto, sendo que o valor de cada termo depende de sua posição relativa, tal como acontece com as unidades da linguagem geral na perspectiva saussuriana.

A base estrutural do significado das linguagens documentárias são as relações que se estabelecem entre os descritores. Entretanto, Tálamo (2001, p.149) adverte que "não basta apenas observar as relações, é preciso reconhecer o princípio subjacente às articulações lógicas para que os mesmos adquiram significado". Nessa perspectiva, as terminologias funcionam como referente do descritor - uma unidade preferencial selecionada conforme interesses cognitivos e pragmáticos de recuperação (LARA, 1999) - fazendo com que a Linguagem Documentária funcione, de fato, como uma linguagem, quer seja no percurso gerativo do processo de codificação, quer seja no percurso de descodificação.

No item "A interação com os usuários", discorremos sobre o avanço tecnológico, o desequilíbrio instaurado nos últimos anos entre o volume crescente de documentação especializada e as capacidades humanas de consumo e as novas perspectivas de resposta da área. Utilizamos como base teórica o artigo de Gardin (2001) intitulado "Para uma remodelagem das publicações científicas: suas relações 
com as ciências da informação", que considera a produção documentária tradicional como meio insuficiente para solucionar o problema da quantidade de textos científicos disponíveis. Entende que o problema não está em torná-los acessíveis como uma publicação tradicional digitalizada, mas principalmente em inová-los, sistematizando o conhecimento novo em formatos mais apropriados para serem consultados (do que lidos), formatos estes que devem ressaltar proposições, argumentações, estruturas de raciocínios e conclusões. No nosso entender, esses formatos a que se refere o autor devem ter aderência aos meios que os veiculam, por exemplo, a maneira como os conteúdos são organizados em um CD-ROM difere do formato de texto tradicional, pois a fragmentação dos tópicos não compromete a unidade e favorece a consulta.

No ambiente digital, a noção tradicional de documento - um objeto constituído de um suporte e de uma inscrição - é diluída e substituída pela noção de dados estruturados mais forma. Digitalizados, documentos textuais e documentos audiovisuais podem conviver sobre uma mesma plataforma e serem acessados concomitantemente. Essa possibilidade tecnológica e a linguagem de hipertexto propiciam a condensação teórica e a possibilidade de consulta dentro de um padrão lógico e coerente, conforme sugere Gardin (2001). Esclarecemos que, embora a reflexão sobre os documentos digitais seja de grande importância para a área, optamos por não explorá-la neste texto, cujo foco principal é a informação como mensagem.

O Capítulo 4, intitulado “As experiências para a transferência da informação das instituições públicas", propõe-se a relatar os meios e formatos de transferência de informação utilizados pelo Cepam na transição para o que designamos sociedade da informação, em que a gestão pública, sob os desígnios da democracia, se pauta pela transparência e compromisso social. Transparência nesse campo significa, antes que qualquer postulado teórico, respeito à coisa pública, satisfação à população, prestação de contas ao cidadão, possibilidades de desenvolvimento político, participação, deixar ver, mostrar, dar visibilidade. Contudo, pode aportar sentido diferente se o nosso objetivo for valorizar os atos da fala no ambiente organizacional. Nessa abordagem, o conceito de transparência quer dizer o que se realiza no "piloto automático", se faz sem perceber, por hábito, falta de atenção, costume, por equivoco e, principalmente, por inércia ou acomodação. Segundo Fernando Flores (1986), um dos passos para a 
mudança de cultura e modernização do setor público está na quebra desse tipo de transparência ${ }^{4}$, na percepção das inquietações, no que se declara, nos compromissos, nas afirmações. "A hermenêutica conectada ao speech acts de John Austin (1962) permite a Winograd/Fernando Flores construir um programa, o COORDINATOR, que apoia e não substitui as conversações e os compromissos no marco das empresas" (CAPURRO, 2003). Esse argumento, a despeito da digressão aparente, ajuda-nos a compreender a experiência do Cepam enquanto instituição pública comprometida com a informação e com seu usuário. Apesar de apresentar razoável sucesso no atendimento prestado aos municípios, de forma presencial, durante 40 anos, hoje, procura apoiar-se no uso das novas tecnologias, uma ação inevitável e necessária. Por um lado, procura ganhar visibilidade, reafirmando sua capacidade informativa junto às instituições governamentais e não-governamentais produtoras e difusoras de informações para os municípios (sua condição de existência e de continuidade); por outro, precisa estar preparada para atender adequadamente às demandas recebidas e também respondê-las antes mesmo que elas se conformem em perguntas (manter qualidade e pertinência).

Assim sendo, a Instituição revê seus modos e meios de disponibilizar informações aos municípios. Cria formatos específicos e adota a internet para responder às solicitações que lhes chegam. Usa o site para divulgar informações de interesse municipal, sejam as produzidas internamente, sejam as produzidas por outros órgãos do governo ou entidades da sociedade civil. Nesse aspecto, atua como filtro disseminando sua produção e divulgando o conhecimento disponibilizado por parceiros. A idéia é privilegiar a informação, organizá-la para que possa transitar adequadamente e chegar ao seu destino sem impacto negativo, isto é, em condições de ser compreendida e absorvida pelo público usuário. No âmbito deste capítulo vamos analisar duas práticas da Instituição e, sobretudo, verificar se as iniciativas selecionadas se aproximam da noção de filtragem utilizada pela Ciência da Informação.

A figura abaixo apresenta o resumo dos principais conceitos, modelos e teorias utilizadas no desenvolvimento deste trabalho.

\footnotetext{
${ }^{4}$ Noção de "quiebres": interrupção da rotina com objetivo de aprendizagem. Quando se muda o foco de observação, ações, objetos e compromissos se revelam. Curso "Desenho de Conversas nas Instituições: a Comunicação no Cotidiano", por Heloisa Nogueira e Klaus Schubert, realizado no contexto das atividades de Planejamento Estratégico do Cepam, em maio de 2008.
} 
Figura 1 - Quadro-resumo do referencial teórico

\begin{tabular}{|c|c|c|c|c|c|c|c|}
\hline Conceitos, modelos e teorias & \multicolumn{7}{|c|}{ Autores citados } \\
\hline $\begin{array}{l}\text { Informação como estrutura } \\
\text { significante }\end{array}$ & \multicolumn{7}{|c|}{ Barreto 1994, 1996, 2002} \\
\hline $\begin{array}{l}\text { Informação como bem público e } \\
\text { mercadoria }\end{array}$ & \multicolumn{7}{|c|}{ Tálamo e Kobashi 2003} \\
\hline Informação como mensagem & \multicolumn{3}{|c|}{ Capurro 1985, 2002} & \multicolumn{4}{|c|}{ Capurro e Hjorland 2007} \\
\hline Paradigma da ciência & \multicolumn{7}{|c|}{ Boaventura Santos 1989} \\
\hline Espiral da cultura científica & \multicolumn{7}{|c|}{ Vogt 2003, 2005} \\
\hline Sociedade da informação & \multicolumn{7}{|c|}{ Castells 1999} \\
\hline Regime de informação & \multicolumn{7}{|c|}{ Gonzáles de Gómez 2002} \\
\hline $\begin{array}{l}\text { Ciência da Informação, } \\
\text { antecedentes e marcos } \\
\text { epistemológicos fundamentais }\end{array}$ & $\begin{array}{l}\text { Ingwerson } \\
1992\end{array}$ & $\begin{array}{l}\text { Le } \\
\text { Coadic } \\
1996\end{array}$ & $\begin{array}{l}\text { Saracevic } \\
1996\end{array}$ & \begin{tabular}{|l|} 
Capurro \\
2002 \\
2003
\end{tabular} & $\begin{array}{l}\text { Capu } \\
\text { Hjor } \\
2007\end{array}$ & $\begin{array}{l}\text { rro e } \\
\text { and }\end{array}$ & $\begin{array}{l}\text { Tálamo } \\
\text { e Smit } \\
2007\end{array}$ \\
\hline O conceito de documento & $\begin{array}{l}\text { Otlet } \\
1934\end{array}$ & $\begin{array}{l}\text { Briet } \\
1951\end{array}$ & $\begin{array}{l}\text { Merriat } \\
1981\end{array}$ & \begin{tabular}{l|} 
Capurro \\
2003
\end{tabular} & $\begin{array}{l}\text { Rodr } \\
\text { Brav } \\
2002\end{array}$ & $\begin{array}{l}\text { íguez } \\
\text { o }\end{array}$ & $\begin{array}{l}\text { Ortega } \\
\text { e Lara } \\
2008 \\
2009\end{array}$ \\
\hline Informação como coisa & \multicolumn{7}{|c|}{ Buckland 1991, 1997} \\
\hline Informação como signo & \multicolumn{7}{|c|}{ Lara 1993, 1999, 2006A } \\
\hline Lingüística documentária & \multicolumn{2}{|c|}{$\begin{array}{l}\text { Tálamo 1992, 1997, } \\
\text { 2001, } 2007\end{array}$} & \multicolumn{3}{|c|}{$\begin{array}{l}\text { Lara 1993, 1999, 2000, } \\
\text { 2006, 2006 A, } 2007\end{array}$} & \multicolumn{2}{|c|}{ Lima 2000} \\
\hline Linguistica estrutural & $\begin{array}{l}\text { Saussure } \\
1969\end{array}$ & \multicolumn{6}{|c|}{ Lopes, 1984, 1997} \\
\hline Terminologia & \multicolumn{7}{|l|}{ Cabré 1999} \\
\hline Linguistica textual & \multicolumn{7}{|l|}{ Kock 2006} \\
\hline A interação com os usuários & \multicolumn{7}{|c|}{ Lara e Tálamo, 2007} \\
\hline Filtragem da informação científica & \multicolumn{7}{|c|}{ Gardin 2001} \\
\hline Disseminação da informação & \multicolumn{7}{|c|}{ Camargo 2006} \\
\hline Práticas informacionais & \multicolumn{7}{|c|}{ Araújo 1999} \\
\hline Política de informação & \multicolumn{7}{|c|}{ Jardim e Marcondes 2003} \\
\hline
\end{tabular}




\subsection{Procedimentos metodológicos}

Estabelecidos os referenciais que orientam o estudo, realizamos o aprofundamento dos quadros teóricos apresentados, que permitirão a objetivação, análise e discussão mais aprimorada do objeto. Também, por meio de experiências concretas, analisamos as práticas informacionais da Fundação Prefeito Faria Lima Cepam para visualizar qual é o estado da arte referente às perguntas levantadas. 


\section{INFORMAÇÃO, CONHECIMENTO ESPECIALIZADO E PERCEPÇÃO PÚBLICA DA CIÊNCIA}

s discussões em torno do conceito de informação não são recentes nem
tampouco acabadas. As diferentes abordagens têm sido amplamente estudadas e confrontadas entre disciplinas, em épocas distintas, e para atender a diferentes propósitos. Grosso modo, a maioria dos embates prioriza melhorar o entendimento sobre o fenômeno informação, sua natureza e delimitação e, ainda, como a informação transgride a sua própria condição e se transforma em conhecimento.

Hoje, pode-se dizer, sem sombra de dúvida, que a informação assume diferentes conformações, cada qual compatível com os fundamentos do campo disciplinar que lhe dá existência. Se, por um lado, o termo informação tende à ambiguidade e à perda de sentido global, por outro, elucidado está que a informação, enquanto "noção relacionada com a cognição e comunicação humana, é um conhecimento inscrito (gravado) sob forma escrita (impressa ou numérica), oral ou audiovisual” (LE COADIC, 1996, p. 5).

Para Barreto, o conhecimento é a razão de ser da informação, esta conceituada como uma estrutura significante, com a competência de gerar conhecimento para o indivíduo e seu grupo. Em primeira instância, a informação é estoque, “dados em uma memória - seja em dispositivo convencional ou em sistema digital - inseridos com a intenção de posterior recuperação" (BARRETO, 2002, p. 68). Mas não a prática da informação, aquilo que acontece fora dos estoques como ação do homem sobre o ambiente: isso difere de objeto, de lugar, de substância e de distância... é fluxo, redução de incerteza, é novidade, é variedade, é sentido. Os fluxos de informação estão relacionados, por um lado, com o conhecimento, que é algo pessoal que acontece no interior dos seres humanos em decorrência de uma ação de comunicação, uma espécie de "viagem solitária" provocada pelos efeitos cognitivos da informação sobre o sujeito, fator este que torna o conhecimento mutável, intransferível e impossível de ser gerenciado em nível organizacional; por outro lado, os fluxos são controlados por aqueles que detêm os estoques, pois são eles que determinam as condições de 
distribuição e consumo da informação e controlam o conhecimento. Segundo Barreto (2002, p. 4) "os produtores de informação não podem dizer ao indivíduo o que pensar, mas podem induzir sobre o que pensar". Desse modo, a "questão da informação" também tem que ser pensada dentro de seu quadro de produção, que abrange a organização, o armazenamento, a distribuição e o consumo, como qualquer outra mercadoria.

Tálamo e Kobashi (2003), reiterando a importância dessa reflexão, fortalecem a discussão no que se refere à oferta, ao acesso e ao uso da informação nas sociedades contemporâneas. Fazendo uma analogia com a estrutura e o fluxo de bens, esclarecem que a informação é um recurso estratégico para a organização e controle social e para produção de bens, é uma mercadoria e um bem público cuja carência provoca ausência de conhecimento. Carência e escassez, explicam as autoras, são resolvidas com organização de estoques e com políticas que transformam os estoques em fluxos, ou seja, o objetivo é que os sujeitos capturem os fluxos promovendo a ação de conhecer. Mas o consumo propriamente dito, o uso da informação no sentido da ação de conhecer, não se resolve somente com a distribuição e aumento de acesso, exige uma moeda de troca que, no caso, é a cognição e o capital cultural, sem os quais a informação não se transforma em conhecimento (Tálamo e Kobashi, 2003). Em países como o Brasil, o consumo da informação passa pela educação e sua produção/distribuição está condicionada ao poder político dos governantes, ao poder econômico dos meios de comunicação de massa e ao viés ideológico de universidades e detentores do saber. A oferta de informação no País não é baixa, contudo, há pouco conhecimento disponível na sociedade, concluem as autoras.

Segundo Barreto (2002, p. 71-4), na história da Documentação ou na sua transição para o que se denomina hoje de Ciência da Informação, são verificados três momentos marcantes cuja importância resultou no reposicionamento do setor:

○ Do pós-guerra até 1980, "crise de tempo" - abrangeu os estoques e os fluxos de informação da época e foi resolvida com a chegada da informática. O desafio consistia em como lidar com o grande número de documentos, configurando o que se denominou de "caos documentário", e produzir respostas rápidas com a tecnologia 
precária da época. Os mecanismos de atendimento às pesquisas dependiam totalmente da intermediação humana e as buscas contínuas nos estoques, uma de cada vez, alongavam demais o tempo de resposta.

○ De 1980 até 1995, "tempo da relação informação conhecimento" - a ênfase recai na ação da informação na coletividade. A reflexão, o ensino e a pesquisa passam a considerar a melhor forma de transmissão da informação e a realidade dos receptores. O foco é o fluxo externo - a ação de comunicação - e o período se caracteriza por uma postura que concede maior importância aos aspectos cognitivos que determinam a transferência e uso da informação.

- De 1995 em diante, "tempo do conhecimento interativo" - a Ciência da Informação sofre o impacto da tecnologia e reorganiza todas as suas atividades, tendo em vista que a realidade virtual impõe uma mudança de paradigma, em que informação, conhecimento especializado e comunicação são fatores associados na mudança da face da sociedade.

Castells (1999, p. 32), a despeito dos paradigmas firmados pela revolução industrial, argumenta que a tecnologia possibilita a construção de uma nova ordem mundial. As bases materiais da sociedade (especialmente o capital e o trabalho) foram remodeladas pela informação e pelas facilidades comunicativas proporcionadas pelo processo tecnológico. Nesse contexto, os diferentes setores, e a sociedade de maneira geral, se mobilizaram para absorver os benefícios e aplacar as complexidades decorrentes. A nova sociedade apresenta uma nova estrutura social, a sociedade em rede, uma nova economia baseada na informação, e uma nova cultura, a cultura da virtualidade do real.

O autor refere-se a esse momento histórico como um processo de reestruturação do sistema capitalista, denominando-o de Sociedade Pós-Industrial e Sociedade Informacional, e esclarece que, "no novo modo informacional de desenvolvimento, a fonte de produtividade acha-se na tecnologia de geração de conhecimentos, de processamento de informações e de comunicação de símbolos” (CASTELLS, 1999, p. $32)$. 
A informação e o conhecimento sempre foram essenciais ao processo de desenvolvimento, mas o que é específico desse modo "é a ação de conhecimentos sobre os próprios conhecimentos como principal fonte de produtividade", ressalvando que "a tecnologia não determina a sociedade" (Idem, p. 35). Ao contrário, as bases culturais da sociedade, organizada em redes de informação eletrônica, por exemplo, estão nos movimentos sociais que, com sua experiência em manipular os códigos culturais, seu espírito comunitário, interdependente, cosmopolita e pouco politizado (no sentido de tomada de poder) constituem o solo necessário para florescência das inovações tecnológicas.

Na ciência, as crises de paradigma são crises de degenerescências, explica Boaventura Santos (1989, p. 18):

\begin{abstract}
atravessam todas as disciplinas, ainda que de modo desigual, e que as atravessam de um modo mais profundo. Significam pôr em causa a própria forma de inteligibilidade do real que um dado paradigma proporciona e não apenas os instrumentos metodológicos e conceituais que lhe dão acesso, como acontecem nas crises de crescimento.
\end{abstract}

As mudanças atuais são crises de degenerescência porque atingem o paradigma epistemológico da ciência. Foram questionados os sistemas que referenciam as coisas e desse questionamento surgiu uma mudança de concepção no âmbito do entendimento do que é conhecimento científico. Toda crise instaura uma maneira diferente de organização e, consequentemente, outras formas de representação, aderentes e significativas aos desejos e possibilidades do homem de uma época.

Neste século o conhecimento científico se torna mais flexível, rejeita as posturas dogmáticas que atribuíam à ciência a condição de saber irrefutável, valorizando mais o método do que as variáveis históricas, políticas e socioculturais. A ciência, na atualidade, é entendida como uma prática social que incorpora os avanços tecnológicos como ferramenta de trabalho e como um objeto de estudo.

Em síntese, o paradigma informacional e tecnológico que caracteriza a atualidade mudou significativamente a relação do homem com a informação e a comunicação. A distância que separa um usuário de uma informação desejada é hoje 
uma distância cognitiva e cultural. Se, por um lado, o simples aumento do estoque mundial de informação multiplica exponencialmente a disponibilidade de informação para uso em função da facilidade de busca simultânea em estoques diversos, por outro, essa oferta também eleva as dificuldades de recuperação, tendo em vista a relevância dos resultados que, na maioria das vezes, são pouco expressivos frente à quantidade recuperada.

Diferentemente dos bens naturais, da água, do ar, dos minerais, das florestas, que estão disponíveis na natureza para consumo do homem, a informação, para existir e poder ser consumida, depende do trabalho humano, que lhe dá materialidade, configurando-a na face visível e palpável do conhecimento. Enquanto o conhecimento é um legado individual, um "acervo pessoal” (BARRETO, 2002, p. 68), resultado da trajetória diferenciada das inteligências e das experiências humanas, a informação é "um bem simbólico, produto do relacionamento cultural dos homens com o meio em que vivem, é um recurso inesgotável que se elabora, organiza e circula no interior da linguagem” (KOBASHI e TÁLAMO, 2003, p. 9).

Tal pressuposto explica as dificuldades no âmbito da transferência da informação. Primeiramente, para que um conteúdo alcance a condição de informação e circule socialmente é necessário que ele seja submetido a um processo de codificação e de decodificação. Em outras palavras, que seja representado e/ou formatado de uma maneira que possa ser compreendido enquanto oferta de sentidos pela comunidade usuária. Na opinião de Rafael Capurro (2003), essa ação insere-se no âmbito da comunicação científica porque se refere às construções discursivas transformadas em mensagens ou à produção científica propriamente dita, registrada em documentos e em parte da memória social. A Ciência da Informação, porque tem suas raízes no estudo dos problemas relacionados à circulação de mensagem, também integra esse circuito, dinamizando-o. Na base de sua edificação estão usuários e documentos (conhecimento) e sua missão é aproximar esses dois universos por meio de processos que tornem possíveis e compreensíveis a "oferta de sentidos (elaboração de mensagem) e a seleção de sentidos (a recuperação de informação)" (CAPURRO, 2003 sobre LUHMANN, 1987). Assim sendo, no plano da ação, os objetivos da Comunicação Científica integram os da Ciência da Informação, que são focados na circulação do conhecimento 
e possibilitados pela difícil tarefa de seleção de conteúdos potencialmente informativos, porque parametrados no suposto interesse das comunidades. O valor de tais conteúdos está na sua possibilidade de transmutação em informação pelo usuário e na solução de um problema. Portanto, conhecer o usuário real da informação, seus formatos e meios preferenciais de enunciação e recepção são fatores relevantes para eficiência e eficácia dos sistemas, bem como para o avanço da pesquisa técnico-científica.

Em segundo lugar, é preciso admitir que, mesmo dentro de um segmento usuário específico, a transferência da informação ocorre em uma situação de comunicação complexa, que envolve uma rede de fatores de ordem linguística, cognitiva, sociocultural e interacional, e que as formas de mediação adotadas, às vezes, são insuficientes para controlar, sozinhas, o processo de recuperação. Nem sempre a instância de produção consegue prever todos os raciocínios e estratégias adotadas pelos usuários no momento de busca da informação. Segundo Lara

cada usuário estabelece, a seu modo, uma formulação baseada na sua experiência colateral e nas suas necessidades particulares, portanto, quanto mais a fonte produtora conseguir explicitar e qualificar as representações oferecidas, mais chance os usuários terão de recuperar informações relevantes e pertinentes aos seus propósitos (1999, p. 142).

Assim sendo, cabe à Ciência da Informação procurar formas de responder adequadamente aos complexos problemas de produção/recepção da informação, gerados pelo acesso e interatividade, aperfeiçoando seus instrumentos de mediação (política de indexação, linguagem documentária, formatos de transferência, indicadores de acompanhamento de necessidades e de uso de informação) com a finalidade de melhorar a oferta à sociedade e a subsequente apropriação.

No que concerne ao conhecimento especializado, é indiscutível que também os cidadãos necessitam de informações científicas para gerir o seu dia a dia e não permanecer ignorantes frente aos avanços científicos, aprisionando-se em comportamentos prejudiciais a si próprios e à sociedade. É indiscutível também que nesse aspecto dependem cada vez mais das fontes de divulgação científicas que atuam 
como intermediárias, transformando o discurso especializado da ciência em informações passíveis de serem entendidas e absorvidas socialmente (CAMARGO, 2006, p. 39).

Vogt (2005) vem militando sobre a importância da percepção pública da ciência, um tema bastante atual porque trata "de compreender a dinâmica complexa das interações entre ciência, tecnologia e sociedade, dando voz à opinião pública" (p. 12). O objeto material do tema é a comunicação social da ciência, especificamente, a reflexão sobre metodologias e instrumentos com a intenção de subsidiar o "avanço em direção a um modo de gestão e de controle social mais democrático no campo da ciência e tecnologia" (Idem).

A pós-modernidade faz a revisão da ciência moderna, envolvendo seus princípios e hipóteses fundamentais, seus métodos de aferição e suas formas de relacionamento, colocando-a em questionamento tanto no plano científico como no plano social. Neste contexto, aperfeiçoar as formas de comunicação da ciência representa um ponto fundamental, pois a ação de informar e a de sentir-se informado mobiliza a sociedade para compreender, legitimar ou rechaçar o conhecimento empírico e os avanços científicos.

Boaventura Santos (1989, p. 26-7) é da opinião de que todo discurso científico é um discurso anormal, inteligível no âmbito institucional da ciência, mas de difícil assimilação pela opinião pública (discurso normal). A única possibilidade de aproximação desses dois universos se dá pela hermenêutica, desde que seja uma hermenêutica crítica, criada a partir da revisão da própria epistemologia enquanto uma prática social.

Capurro (2003) também reconhece que o conhecimento está ligado à ação de interpretar e de anunciar, porém advoga que, do ponto de vista epistemológico, liga-se também à ética, acrescentando que "as proposições epistemológicas atuais (referindo-se ao século XXI) são tecnológicas e naturalistas", querendo dizer que se ocupam também dos "seres digitais". 
Entendemos, portanto, que o alerta de Boaventura não se refere somente ao discurso da ciência, no sentido retórico, ou de uma nova estética, mas, sobretudo, às premissas éticas. Em outras palavras, para o autor, a questão da comunicação do conhecimento científico não deve ser vista somente como um problema semântico ou vocabular, pois, se assim fosse, não haveria transgressão alguma e tudo continuaria no mesmo patamar epistemológico dos discursos anteriores. Adotando uma visão social, segue afirmando que o "objetivo existencial da ciência está fora dela" (1989, p. 29), para expressar que a ciência não se justifica pelo estudo sobre as causas das coisas, mas, principalmente, pelas consequências que tais estudos ocasionam no tecido social.

Nesse sentido, a pós-modernidade tenta democratizar a ciência, incorporando nas suas decisões o interesse social, a abordagem interdisciplinar, a ordem a partir da desordem e a possibilidade de incerteza tão renegada na postura científica precedente. Boaventura (1989, p. 29) esclarece que, em relação à ciência clássica, a pósmodernidade encerra uma segunda ruptura. A primeira, chamada de modernidade, procurava racionalizar o senso comum, opondo-se à opinião pública como postura crucial para fazer com que o pensamento científico prevalecesse no comando do mundo. Já a ruptura atual caracteriza-se pelo reencontro da ciência com o senso comum. Tratase de um reencontro transformador, um vir a ser, somente possível quando a ciência e o senso comum se superarem no sentido de uma nova construção.

Os estudos de Vogt (2003, 2005) propiciam o entendimento de que a construção desse patamar passa pela percepção pública da ciência, pela informação e por um processo cultural protagonizado por cidadãos; comunidade científica amplo senso; governo; equipamentos culturais e mídias em geral. A espiral da cultura científica proposta por ele representa a dinâmica de produção e de socialização do conhecimento científico. O processo tem início com a difusão no âmbito institucional da ciência e vai evoluindo para dois planos intermediários de formação - um responsável pelos novos cientistas, iniciado já no ensino fundamental e médio, e outro sensibilizador e informativo, focado na juventude e desempenhado pelos museus e feiras de ciência para só então atingir a opinião pública. 
O interessante da proposição é a possibilidade de visualização dos fluxos de circulação da informação em ciência e tecnologia na sociedade contemporânea, "os contextos de adesão possíveis, já que não se acredita que a informação seja um dado puro, mas dependente de interpretação" (LARA, 2006). A progressão da espiral na linha do tempo e do espaço simboliza que o retorno inevitável ao primeiro quadrante traz consigo uma mudança cultural e um avanço social. Isto é, supõe que o estreitamento das relações entre ciência e sociedade depende da construção de vínculos, da troca e do compartilhamento, como qualquer processo cultural, e não somente da oferta de informação ou do acesso facilitado pela tecnologia. Neste aspecto, a mediação necessária para a transferência e assimilação fica a cargo da competência e desempenho das várias instâncias envolvidas, algumas com papel educacional e político mais acentuado, outras com responsabilidades informativas, tais como a mídia em geral. Acrescenta-se que as bibliotecas, os centros de informação e outros aportes informativos, organizadores e disseminadores de informações científicas, atuam sobre as instituições e atores diversos, contribuindo para que a passagem da informação de um quadrante a outro aconteça corretamente. Segundo Camargo (2006, p. 44) "a informação sai da sociedade e a ela deve retornar, completando, assim, seu ciclo, e mantendo seu necessário fluxo de retroalimentação constante”. O desenho explicita a proposta.

Figura 2 - A espiral da cultura científica de Vogt, 2003, p. 5

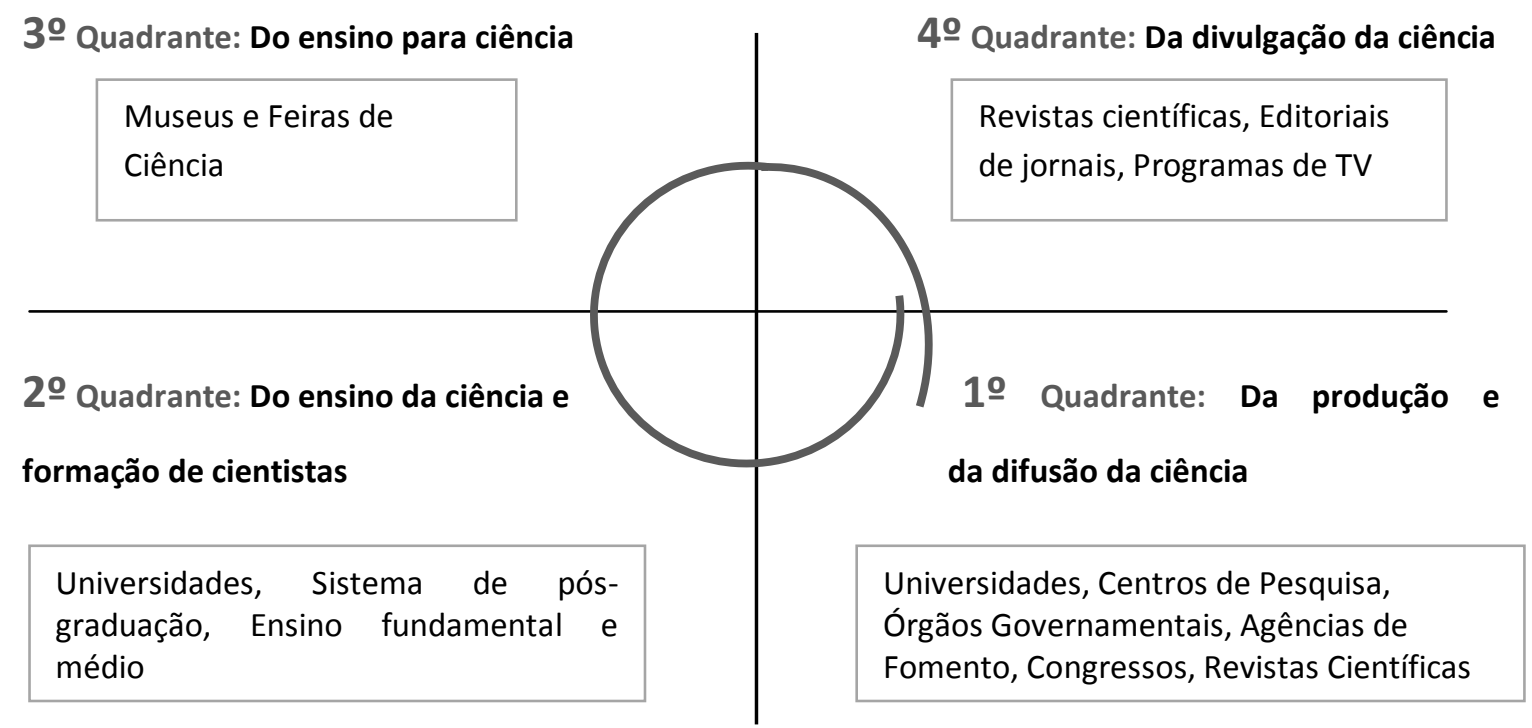


Como já comentamos em parágrafos anteriores, a informação é a única mediação possível entre ciência e sociedade, e, assim sendo, sua organização para transferência é fator fundamental de progresso. No sentido de mensagem, seu objetivo é aproximar o conhecimento da realidade do indivíduo, agregando valores ao estágio cognitivo anterior do mesmo, fomentando a sua produção intelectual e a socialização de novos conhecimentos, pois o processo é aberto em espiral. Entretanto, para que isso se efetive, é preciso que haja entendimento comunicativo, isto é, a utilização de códigos comuns, formatos e meios adequados que promovam a apropriação necessária na instância da recepção da informação. Esse ciclo de recepção (percepção e seleção de valores), geração (agregação de novos sentidos) e transferência (ação de difusão e de divulgação) é contínuo, não se equiparando a um processo acabado. Também a prática dos profissionais da informação é baseada na interação comunicativa, embora, no caso, os códigos mediadores sejam os valores institucionais expressos na política de indexação, na linguagem documentária de cunho terminológico e nos instrumentos gestados a partir do retorno dos usuários, num processo realimentado.

\section{Figura 3 - Códigos comuns entre emissão e recepção e processo realimentado}

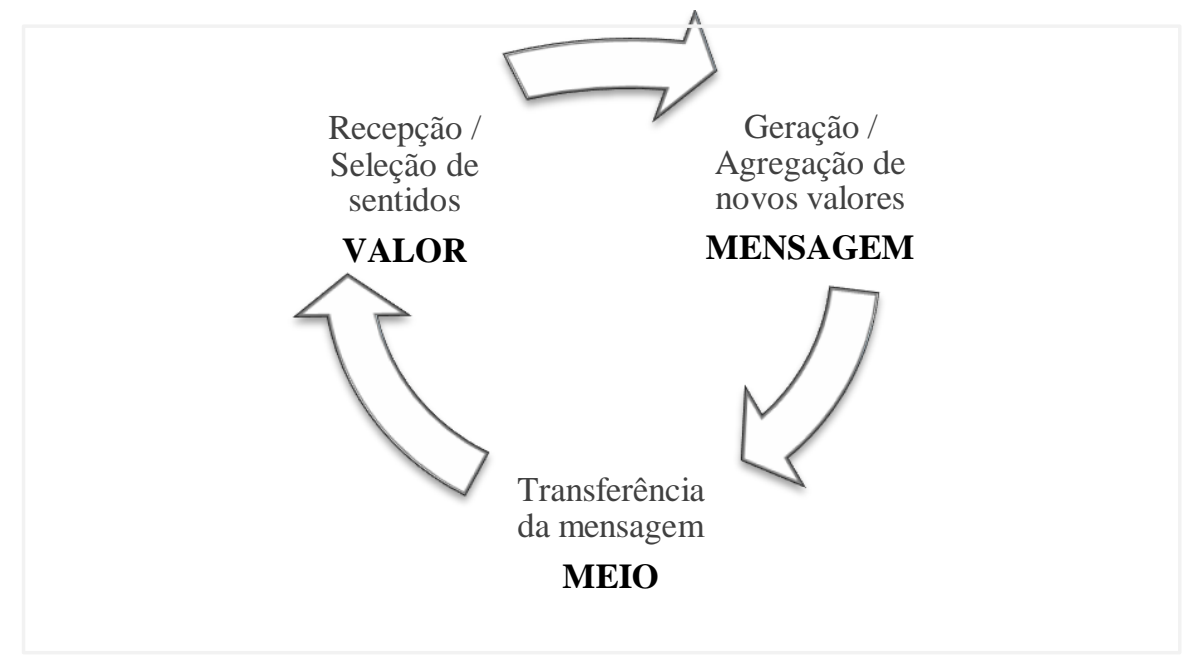

Na perspectiva de Vogt, "uma sociedade estará mais ou menos consciente da importância da ciência na medida em que a questão de 'para onde se dirigem a ciência e a tecnologia' constitua um tópico da cultura geral e do debate social” (2005, p. 11). Nesse particular, é necessário que se faça o acompanhamento do processo cultural que insere os cidadãos nos rumos da ciência e da tecnologia e vice-versa, a comunidade científica no espaço público. A realização de enquetes, de pesquisas e a busca de 
indicadores que expressem os "tipos de relações que a sociedade estabelece com a ciência e o sistema científico-tecnológico: interesse, conhecimento e atitudes" (Idem, p. 6) são instrumentos importantíssimos, porque proporcionam os parâmetros numéricos imprescindíveis para se medir ou avaliar "o quão cientificamente orientada se encontra uma sociedade em um momento histórico determinado" (VOGT, 2005, p. 12).

Em conclusão, pode-se afirmar que, na sociedade da informação e do conhecimento, a maneira como as informações chegam à sociedade influi diretamente nas conquistas forjadas pela mesma. O modelo de comunicação clássico que

\begin{abstract}
postulava a divulgação como tradução, onde a fonte produtora despeja suas informações na sociedade por meio de um canal considerando que a instância de recepção é formada por um público homogêneo, passivo, vítima de um déficit cognitivo/cultural, vem sendo substituído por uma série de alternativas (VOGT, 2005, p.8).
\end{abstract}

Todas as alternativas são dotadas de uma lógica subjacente que objetiva compreender e valorizar os aspectos cognitivos, culturais e, principalmente, a participação do público receptor nesse processo de inclusão em que o universo da informação e o universo social, reciprocamente, num movimento de atração e repulsão, se reconstruam criticamente com base em informações.

Neste capítulo procurou-se mostrar como as relações entre o conhecimento especializado e a sociedade podem ser estabelecidas para atender a um direito fundamental democrático, que é o direito à informação. Considerou-se que, para atingir adequadamente a opinião pública e mudar o estado da sociedade, é necessário que o conhecimento especializado seja analisado, processado adequadamente em informação e divulgado por meio de ações de comunicação diferenciadas, mais eficientes e responsáveis no que se refere ao discurso científico. Percebe-se, pela espiral do conhecimento, que o ato de informar algo a alguém tanto quanto o de sentir-se informado não é uma operação mecânica, mas seletiva e tributária de um processo cultural que pede a participação e a construção de vínculos entre comunidades discursivas. Também é um processo dinâmico e situacional, pois o teor dos conteúdos (mais especializados ou mais genéricos, no sentido de mais informativos ou menos informativos) varia em função das circunstâncias dos receptores que também não são 
estáticas. Tal constatação torna ainda mais complexa as ações dos sistemas de informação, que, para poderem informar, têm que gerenciar a 'instabilidade natural' da oferta e das necessidades do segmento usuário. Acredita-se que, por parte da recepção, a percepção da utilidade de um determinado conteúdo pode levar à busca de outro, e parece ser essa a força propulsora do consumo da informação na sociedade e da mudança das estruturas de conhecimento. No que cabe à Ciência da Informação, a relação comunicativa se desenvolve com base em instrumentos lógico-semânticos, de cunho terminológico e sociolinguístico. 


\section{ORGANIZAÇÃO DA INFORMAÇÃO, ACESSO E TRANSFERÊNCIA}

\begin{tabular}{|} 
Ste capítulo tem por objetivo explorar as diferentes abordagens da \\
informação inseridas no atual quadro teórico da Ciência da Informação,
\end{tabular} pois considera-se que o entendimento de tais conteúdos contribui para a constituição de formas de gestão mais adequadas, tendo em vista o acesso e a transferência. Discute também o problema da crescente massa informativa disponível na sociedade contemporânea, incluindo a variedade de documentos digitais e problemas decorrentes.

Organizar, palavra relacionada à Biblioteconomia, significa, para o mundo científico, social ou profissional, a possibilidade de conhecer sua documentação e sobre ela agregar novos sentidos. Assim sendo, tal processo não tem valor nele mesmo, mas na informação e, sobretudo, na ação que a informação pode desencadear sobre os sujeitos individuais ou coletivos.

As razões de ordem patrimonial que por si só justificavam a formação dos acervos foram substituídas pelas funções de uso e pelo atendimento de demandas determinadas, tendo em vista ser a informação uma unidade de valor para o mundo contemporâneo. Tais demandas não almejam somente a localização de um documento, mas o acesso ao significado de seus conteúdos dentro de um conjunto de probabilidades de resposta. Nessa perspectiva, a informação é uma "organização em si" (BARRETO, 1994). Partindo da documentação que lhe dá existência compõe-se em mensagem porque integra um processo de produção que reúne, analisa, seleciona, codifica, reduz, classifica e armazena com a finalidade de transferência e circulação. Em outras palavras, a informação está situada no universo da linguagem e nesse patamar sua existência depende da comunicação ou do entendimento alcançado entre as instâncias de produção e de recepção. Segundo Barreto (1994, p. 4), a informação só se consolida mediante uma ação de comunicação mutuamente consentida entre a fonte (os estoques) e o receptor. 
O custo de produção da informação é alto e tal empreendimento é sempre analisado em termos de custo-benefício, avaliado quanto a seus resultados, cuja expectativa implica a mudança de uma situação qualquer em função de conhecimentos agregados. Isto não quer dizer que a organização e o controle dos repositórios para uso futuro não sejam importantes. Barreto (1994, p. 4) explica que eles possuem competência para gerar conhecimento, e que a informação estática por si só não produz conhecimento algum. A formação de bibliotecas, bases de dados, sistemas e redes, embora sejam unidades fundamentais, justificam-se na atualidade pelas suas funções de transferência e de troca de informação. A informação, encarada como "um produto, uma substância, uma matéria" (ESCARPIT, 1990, citado por LE COADIC, 1996, p. 13), tem um sentido dinâmico relacionado com a sua finalidade de estimular o conhecimento e com ele o desenvolvimento em sentido amplo. Contudo, na prática, ter objetivos e metas definidas, recurso financeiro e tecnológico, ainda não é suficiente para a realização de um bom trabalho documentário com foco na informação. As unidades de informação, amplo senso, engendram operações complexas, pois, sendo o centro de um sistema maior, têm que conhecer e dominar, de um lado, a terminologia dos autores e o conhecimento registrado, e, de outro, a linguagem dos usuários com os seus saberes específicos e necessidades distintas. Como fazer essa ponte entre produção e recepção é o problema. Há controvérsias metodológicas; os interesses são facetados mesmo dentro de um segmento de usuário; o funcionamento dos sistemas de informação envolve competências distintas que têm que se relacionar diuturnamente nas tarefas documentárias, e há muitas, muitas inovações, tanto no campo teórico como na prática profissional e é preciso saber selecionar as mais eficientes.

O avanço tecnológico mudou o quadro do processamento e da recuperação da informação na medida em que "não há mais distâncias que sejam obstáculo à velocidade, nenhuma fronteira detém a informação [...] os sistemas eletrônicos encurtaram o tempo de execução das tarefas de busca e de processamento da informação" (LE COADIC, 1996, p. 8), mas, ao mesmo tempo, a despeito dos fatores positivos, a tecnologia provocou, e ainda provoca, forte impacto nas instâncias de produção e de recepção. Os maiores impactos, do nosso ponto de vista, estão relacionados à construção de interfaces amigáveis, que substituam a mediação presencial realizada pelas unidades de informação, e ao documento digital. Também 
governos e sociedade, enredados pelas facilidades de acesso e pelas possibilidades de circulação de grande massa de informação para além das fronteiras nacionais, não fazem a distinção adequada entre informação e tecnologia, ocasionando, algumas vezes, prejuízos ao setor.

A Ciência da Informação, embora tenha sua origem relacionada à informática, pois nasce formalmente em 1962, em uma reunião no Instituto de Tecnologia da Georgia, também sofre o impacto do avanço tecnológico e vem procurando fazer a interação dos dois campos, de forma a preservar os seus fundamentos relacionados à ciência e à sociedade.

Inicialmente, a Ciência da Informação sofre grande influência da matemática e da comunicação e só mais tarde se aproxima de outras áreas como a psicologia, a linguística e as ciências sociais, firmando-se como campo de conhecimento em 1990 e incorporando uma prática profissional exercida antes dela. Segundo Saracevic (1996, p. 47), a Ciência da Informação

é um campo dedicado às questões científicas e à prática profissional voltadas para os problemas de efetiva comunicação do conhecimento e de seus registros entre os seres humanos, no contexto social, institucional ou individual do uso e das necessidades de informação. No tratamento destas questões são consideradas de particular interesse as vantagens das modernas tecnologias informacionais.

A Biblioteconomia e a Documentação, enquanto disciplinas e área profissional, estão amalgamadas na Ciência da Informação. O campo novo se constrói no conflito pela criação de novas abordagens e pela releitura das teorias existentes, portanto, é natural que conceitos como documentos, textos, linguagem, recuperação da informação, revocação, relevância, bem como suas relações entre si e com outros campos de especialidade, se mantenham, desapareçam ou ressurjam em períodos distintos, com o propósito de responder a cada novo contexto, reafirmando posturas ou fundamentando novas construções teóricas.

Desde o princípio monográfico de Otlet (1934), o objetivo da área é identificar a informação, sintetizá-la para torná-la manipulável e poder estabelecer relações, quer 
com o conhecimento propriamente dito, quer com os usuários que necessitam do conhecimento. Subjacente ao conceito de informação está a questão da organização, pois, sem esse processo, a informação não existe, na medida em que não pode ser transmitida e/ou reutilizada.

Capurro (2003), valorizando esse viés, que trabalha com a representação do universo simbólico, denomina a Ciência da Informação, alternativamente, de ciência da mensagem. Ao mesmo tempo, enfatiza a importância dos estudos sobre o impacto da tecnologia nos processos informacionais, em especial da informação científica registrada em documentos impressos. Em importante trabalho de livre docência, o autor sistematiza a história da área a partir da identificação de três paradigmas epistemológicos:

A Ciência da Informação nasce no século XX sob o paradigma físico; questionado por um enfoque idealista e individualista, sendo este por sua vez substituído por um paradigma pragmático e social [...] por uma epistemologia social, mas agora de corte tecnológico digital. [...] o que aparentemente surge agora - paradigma social - já se encontrava no início, se bem que não como paradigma da ciência da informação, mas sim de seus predecessores, em particular a Biblioteconomia e a Documentação.

Figura 4 - Representação nossa dos três paradigmas de Capurro

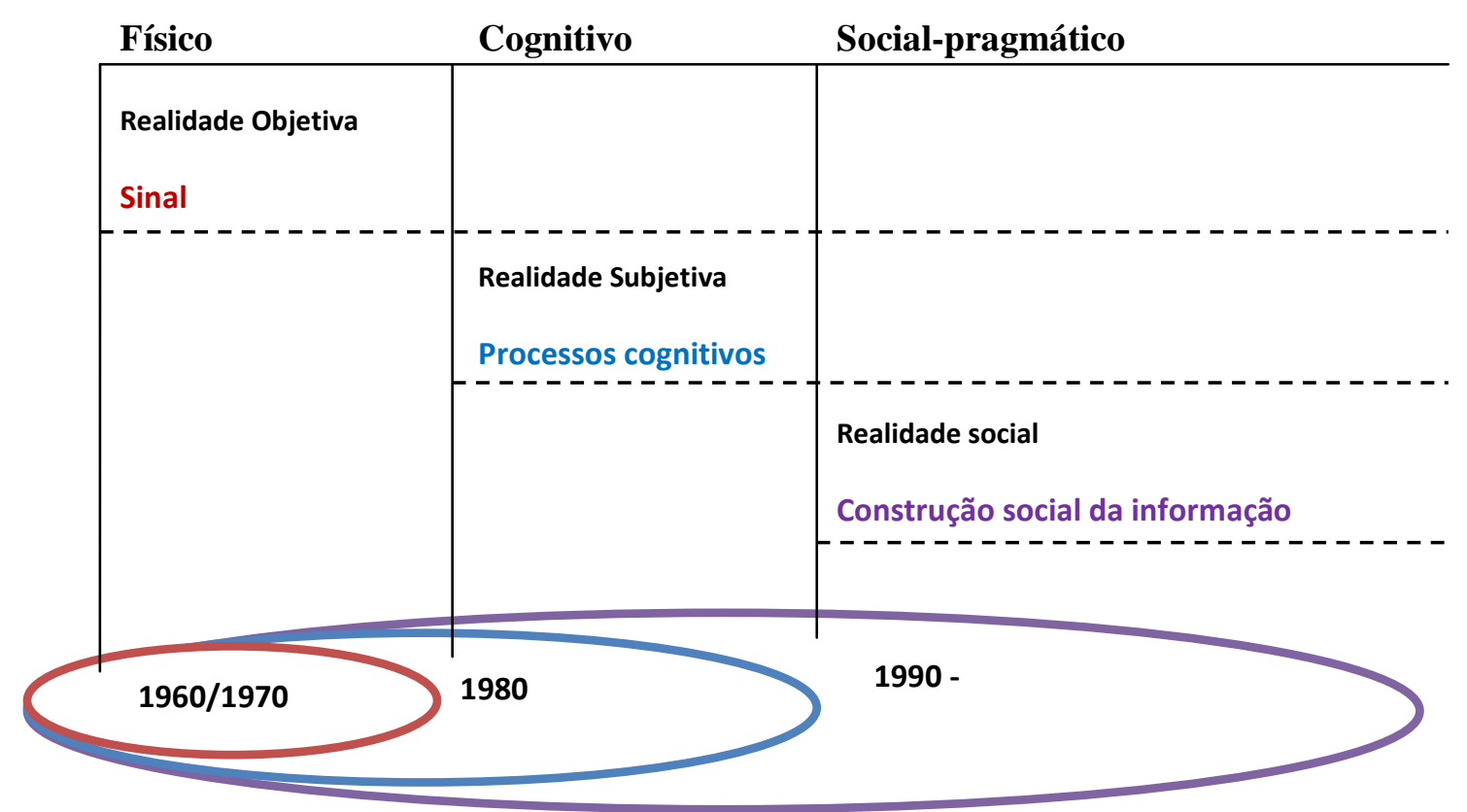


O paradigma físico representa a concepção de informação como realidade objetiva, algo natural, cuja existência está vinculada às suas condições de produção/transmissão, que respondem a um circuito altamente programado e, desse modo, independente de interpretação na instância de recepção. Os Sistemas de Recuperação da Informação desenvolveram-se sob essa referência. A Teoria Matemática da Comunicação, de Shannon e Weaver, concentrava-se, sobretudo, em formalizar um conceito de informação que "pudesse se expressar em unidades físicas", ou seja, procurava "uma forma de codificar eficazmente as mensagens transmitidas com um mínimo de erro e na maior velocidade possível por canais com ruídos" (RODRÍGUEZ BRAVO, 2002, p. 53).

Esse objetivo não abarca todos os interesses da Ciência da Informação, pois trata a informação no sentido de energia e dentro do modelo clássico de comunicação (fonte, receptor, canal, mensagem, sinal e código), omitindo-se frente às características semânticas constituintes das mensagens, e tampouco considerando os esforços mentais despendidos pelos usuários no momento da recepção. Informação é sinal, conforme pode ser visualizado na ilustração abaixo:

Figura 5 - Paradigma físico, gráfico apresentado por Capurro \& Hjorland, 2007, p. 162

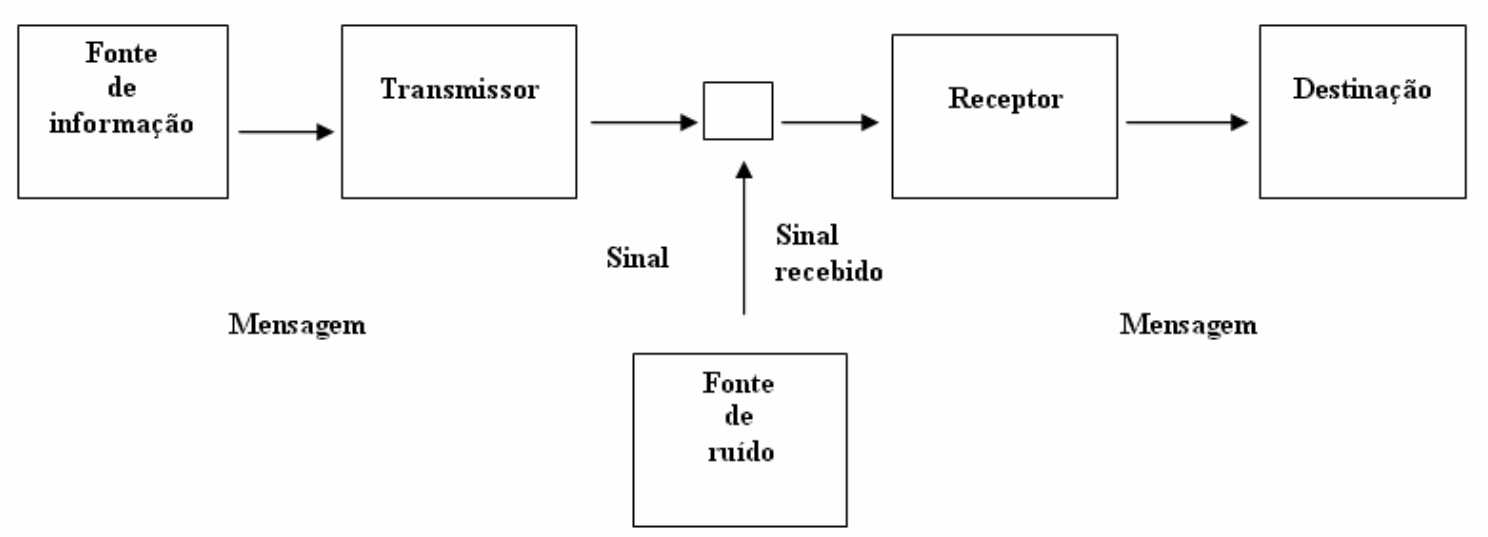


A dinâmica desse modelo, que comandou as pesquisas nos anos iniciais do desenvolvimento da Ciência da Informação, ou seja, até os anos 70, é descrita por Rodríguez Bravo (2002, p. 54):

com a ajuda de uma fonte de energia, um emissor codifica uma mensagem em forma de sinal sobre um canal mediante um conjunto de símbolos e regras de combinação e interpretação comuns ao receptor - o código. Uma vez codificada, o sinal discorre através do canal até chegar ao receptor, ameaçado por fontes de ruído e por processos entrópicos que afetam a qualquer processo energético, sobre os quais deve prevalecer. O sinal é captado pelo receptor, que o decodifica corretamente na medida em que não apresenta deformação por ruído e por entropia.

Buscava-se, na verdade, quantificar a informação partindo "de uma função da relação entre a expectativa do espaço de sucesso alternativos considerados prováveis antes da recepção da mensagem e o número de respostas possíveis que se esperam depois" (RODRÍGUEZ BRAVO, p. 55-6). Ou seja, a informação se define na probabilidade de sinais, e o sucesso de uma recuperação (provável) acaba sendo considerado menos informativo frente àquele que é inesperado. $\mathrm{O}$ receptor tem que dominar cada uma das possibilidades de resposta, o que mostra que o modelo pode ser útil para as aplicações em que a probabilidade é de um para um, como, por exemplo, nos sistemas de perguntas e respostas que funcionam sobre alto índice de previsibilidade. Rodríguez Bravo (2002, p. 57), sintetizando comentários de vários autores, deixa claro que "o sistema de Shannon serve para medir a incerteza do receptor, mas não sua ignorância".

O paradigma cognitivo, ou a informação como realidade subjetiva, surge nos anos 80 como crítica ao modelo anterior, propondo uma virada: "sua premissa básica é que em ambos os extremos de um sistema de comunicação (emissor e receptor) se produzem processos cognitivos" (Idem, p. 61). Desse modo, os fatores subjetivos, tal como o intelecto, desprezados pelo cientificismo de Shannon, vão sendo incorporados paulatinamente ao estudo dos processos de organização e transferência da informação.

Entretanto, por influência da Psicologia, a abordagem cognitivista priorizou os estudos que tinham por interesse o funcionamento da mente, os modelos mentais, não 
fazendo qualquer referência aos contextos socioculturais e linguísticos que também determinam a produção e o uso da informação. Consequentemente, a informação passou a ser concebida como "algo" separado do usuário, desprendida de suas condições ou de suas situações de existência.

Desse ponto de vista, a informação passa a ser entendida como "um estado de conhecimento comunicado" (CAPURRO \& HJORLAND, 2007, p. 190), algo constituído de significação e revestido de propósitos, que se realiza dentro da mente do receptor, com a assimilação de uma mensagem, causando um "efeito". A informação "é a alteração da imagem que ocorre quando se recebe uma mensagem", afirma Pratt (1977, p. 204-20, citado por RODRÍGUEZ BRAVO, 2002, p. 61-2).

Belkin e Robertson, lá pelos idos de 1970, encorpam essa concepção de informação acrescentando a ela a noção de estrutura. Os autores guiaram-se pela seguinte lógica: se a informação é um efeito que muda a imagem sobre as coisas, tal fenômeno corresponde "à estrutura de qualquer texto que é capaz de mudar a estrutura da imagem de algum receptor" (citado por RODRÍGUEZ BRAVO, 2002, p.62).

A evolução dos estudos de Belkin o leva ao conceito de "estado anômalo de conhecimento" do receptor como sendo o propulsor do funcionamento dos sistemas de comunicação. Grosso modo, essa concepção parte do princípio de que a instância de produção de informação (o emissor) possui um modelo de mundo, uma estrutura de conhecimento que deseja comunicar, mas, para que possa ser transferida e lograr êxito, tem que ser processada (modificada pela reescrita, sistematizada, sintetizada, resumida, indexada, etc.) de acordo com seus propósitos e considerando, sobretudo, a estrutura conceitual do receptor. Essa estrutura resultante do processamento e produzida por meio da linguagem, que se equipara a um texto, frisa o autor, é que estará acessível aos receptores potenciais e servirá para motivá-los a utilizar o sistema de informação fazendo perguntas perante o reconhecimento de que há uma falha no seu estado de conhecimento.

Nesta corrente teórica se engajam vários autores. Brookes, com forte tendência à objetividade, traz para discussão a noção de que o "conhecimento é uma estrutura de 
conceitos unidos por suas relações e a informação é uma pequena parte de tal estrutura [...] a estrutura do conhecimento pode ser objetiva ou subjetiva”, e quando se refere às estruturas objetivas, pensa em "registradas" (citado por RODRÍGUEZ BRAVO, 2002, p. 63).

Peter Ingwersen (1992) faz a síntese dos autores citados, esclarecendo os limites entre dados, informação e conhecimento. Dados são signos, símbolos, palavras, números, desenhos, esquemas, qualquer inscrição, potencialmente informativa, presente na sociedade. Sobre eles, o homem pode aplicar a sua capacidade de percepção e as estruturas conceituais armazenadas na sua memória, transformando-os em informação por meio da comparação, da inferência, da combinação, etc. A informação gerada, por sua vez, pode alterar as estruturas de conhecimento existentes, mas, para isso, depende do estado de conhecimento do sujeito e da complexidade da informação percebida.

A colaboração de Ingwersen (1992) pode ser sintetizada na argumentação de que a informação existirá somente se os dados forem percebidos. Além de confirmar que a informação está relacionada com as estruturas de conhecimento (pré-compreensão), ele advoga que esse processo inicia-se no patamar da percepção e só se completa quando introjetada pelos indivíduos e transformada em conhecimento, o que significa incorporada à sua vida prática. Até então tudo é potencial, só o estado de conhecimento modificado pode gerar nova informação.

Segundo Capurro (2003), ainda com "Ingwersen (1992, 1995, 1999), o objeto perdido desse paradigma cognitivo sem sujeito cognoscente que é o usuário" não foi resolvido. Isto porque os estudos do autor se direcionaram para

ver de que forma os processos informativos transformam ou não o usuário, entendido em primeiro lugar como sujeito cognoscente possuidor de 'modelos mentais' do 'mundo exterior' que são transformados durante o processo informacional (Idem).

A abordagem subjetiva torna-se importante para a Ciência da Informação na medida em que, ao longo de suas discussões, incorpora parâmetros sociais e linguísticos e traz o usuário para dentro do processo comunicativo, demarcando uma fronteira clara 
com os estudos anteriores, que se omitiram nesse aspecto. Mas, efetivamente, não considera a recepção, o que justifica o terceiro paradigma.

O terceiro paradigma, denominado paradigma social ou pragmático, incorpora as críticas ao cognitivismo e assinala que no processo de construção da informação tem-se que considerar também as intenções do receptor, pois as duas instâncias comunicativas se requerem e se realimentam. Frohmann explicita:

O ponto de vista cognitivo relega os processos sociais de produção, distribuição, intercâmbio e consumo de informação a um nível numênico, indicado somente por seus efeitos nas representações de geradores de imagens atomizadas. A construção social dos processos informativos, ou seja, a constituição social das necessidades dos usuários, dos arquivos de conhecimentos e dos esquemas de produção, transmissão, distribuição e consumo de imagens, exclui-se, pois, da teoria da biblioteconomia e da ciência da informação (FROHMANN, 1995, p. 282, citado por CAPURRO, 2003).

Tálamo, Lara e outros autores entendem os processos cognitivos associados à linguagem, ou seja, utilizam um enfoque semiótico e linguístico-terminológico para advogarem que a informação só tem existência dentro de um contexto ou situação comunicativa concreta, em que os usuários, como seres sociais, são também portadores de informações e de conhecimentos prévios e integrantes do processo de construção da informação. Em outras palavras, a informação não é só acesso, compreendendo a construção de sentidos dependente da qualidade da representação e/ou de compartilhamento para existir. Nesse sentido, a aderência da informação aos objetivos e propósitos de cada grupo usuário depende do apoio da terminologia.

Buscando soluções que possam viabilizar melhor a interação entre as instâncias de produção e recepção da mensagem documentária, Lara, em texto recente, "partindo de uma noção de texto não como unidade acabada, mas como lugar de interação entre atores sociais, indica a Linguística Textual como fonte promissora de pesquisa" (2007, p. 8). 


\subsection{Informação como coisa}

A informação vista como coisa remete à reflexão sobre o documento. A discussão que interessa aos objetivos deste item começa em 1934, com o Tratado de Documentação de Paul Otlet, para quem o conceito de documento abrangia não só o conhecimento registrado, mas qualquer evidência ou artefato que contivesse, mesmo que potencialmente, a possibilidade de interpretação de uma experiência.

O objetivo do autor era evidenciar e organizar todo conhecimento passível de interpretação existente em qualquer objeto, e não propriamente organizar os objetos. A Documentação, enquanto um campo criado por Otlet, propõe que a informação estruturada nos documentos seja submetida a procedimentos de seleção e de organização (princípio monográfico), que a converterão em outros documentos também passíveis de divulgação. Otlet trabalhou com a idéia de dossiês, que implicava principalmente recortar conteúdos e relacioná-los tematicamente, formando novos registros. Desse modo, é possível reconhecer no princípio monográfico propósito equivalente ao que hoje definimos como informação e acesso. Para o autor, documento era uma unidade intelectual e material, de tal forma que o relacionamento entre documentos formava a documentação, entendida como memória intelectual dos campos científicos (registros do pensamento) e, também, como a única possibilidade de circulação do conhecimento.

Desde Otlet (1934), a área vem se ocupando do conceito de documento e do conceito de Informação, examinando-os em seus diferentes aspectos e gerando padrões de apreensão e de compreensão de especificidades, independentes e até divergentes, se considerarmos como parâmetro preferencial as regras da lógica clássica, que divide para entender, contrapõe para conhecer, distingue para eleger.

Meyriat (1981) define documento como sendo um "objeto que dá suporte à informação, que serve para comunicá-la e que é duradouro" (RODRÍGUEZ BRAVO, p. 85). A definição concentra a principal finalidade dos documentos, que é comunicar uma informação ou poder transferir a qualquer momento uma mensagem. Nessa perspectiva, a noção de documento é vinculada à de comunicação e ambas à de informação, pois, 
sem esta, as outras não se sustentam. No raciocínio de que o documento é suporte da mensagem porque "emitido com função comunicativa e potencialmente informativo para o receptor" (Idem, p. 116), o autor distingue documentos que foram concebidos especialmente para transmitir informação daqueles que só podem cumprir esse papel subsidiariamente. Ilustra seu entendimento com o exemplo de sua bicicleta, argumentando que, no futuro, ela pode se constituir em informação para alguém, mas, naquele momento, sua finalidade é meio de transporte. Há, pois, grande sintonia entre Meyriat e as proposituras de Buckland (1991, p. 43, 44, 46 e 47), que trata a informação como coisa ou objeto (dados, textos, documentos e objetos), considerando que em torno de alguns objetos existe um consenso sobre sua competência informativa que lhe assegura sua condição de documento em qualquer circunstância.

Para Buckland (Idem) a informação se divide em entidade e processo, conforme suas características de tangibilidade e intangibilidade. Neste particular, é importante ressaltar que o autor adota a visão de Wersig, para quem a informação é derivada de três fontes:

- gerada internamente por um esforço mental, sinônimo de conhecimento;

- adquirida pela percepção de fenômenos e pela observação de objetos tangíveis;

- adquirida pela comunicação.

Na categoria entidade, Buckland (1991, p. 43, 44, 46, 47) registra a informação como conhecimento - um conteúdo intangível e o seu contrário, a informação tangível, vista como coisa ou objeto. Na categoria processo, relaciona como intangível o ato de ficar informado e, como tangível, o produto do processamento da informação pelos sistemas, isto é, a construção da representação sobre dados e documentos porque são informativos, querendo dizer que são passíveis de serem compreendidos e oferecidos como mensagem com a finalidade de geração de novas informações e não somente com objetivos de distribuição. 
Figura 6 - Concepção da informação por Buckland ${ }^{5}$

\begin{tabular}{|c|c|c|c|}
\hline & Intangível & Tangível & \\
\hline Entidade & $\begin{array}{l}\text { 1. Informação como } \\
\text { conhecimento }\end{array}$ & 3. Informação como objeto & \\
\hline Processo & $\begin{array}{l}\text { 2. Informação como } \\
\text { processo. "Ficar } \\
\text { informado" }\end{array}$ & $\begin{array}{l}\text { Processamento da } \\
\text { informação. Elaboração } \\
\text { pelo sistema de informação } \\
\text { de uma nova informação } \\
\text { como objeto. }\end{array}$ & $\begin{array}{l}\text { Campo } \\
\text { da CI }\end{array}$ \\
\hline
\end{tabular}

Claro está que o campo da Ciência da Informação é o "mundo" dos objetos e dos processos tangíveis, sejam eles reais ou simbólicos.

Rodríguez Bravo (2002, p. 68) esclarece que o ato de informar, que caracteriza os sistemas de informação, é dependente da comunicação intencional entre fonte e receptor. Entretanto, essa comunicação só pode ser estabelecida a partir do processamento das informações. Trata-se da transformação de uma informação objetiva, uma entidade potencialmente informativa cuja existência, além de ser externa ou anterior ao fluxo comunicativo, é generalizável, um documento, portanto, em informação subjetiva - aquela a que se chega por meio do pensamento, desde que localizada em um contexto situacional e temporal específico. A autora enfatiza que

a busca de informação e o uso só podem ser descritos como atividades construtivas do processo pessoal de dar sentido [...] enquanto que a necessidade de informação que os usuários têm só pode ser solucionada com informações objetivas, as quais são processadas pela mente humana para acrescentarem algo novo ao que já existe em seu conhecimento (RODRÍGUEZ BRAVO, 2002, p. 69)

\footnotetext{
${ }^{5}$ Reproduzimos figura apresentada em sala de aula pela Prof ${ }^{a}$ Johanna Smit em 2007.
} 
Nessa direção, Capurro e Hjorland (2007, p. 150) comentam que os conceitos de objetividade e de subjetividade só interessam no seu sentido prático, isto é,

na avaliação das diferentes perspectivas que podem delimitar, em um contexto particular, o que está sendo considerado informativo, seja isto, uma coisa ou um documento. [...] O conceito de interpretação ou de seleção pode ser considerado uma ponte entre estes pólos de tensão" que são os conceitos de objetividade e subjetividade. [...] A coisa mais importante em Ciência da Informação (como política de informação) é considerar a informação como uma força constitutiva na sociedade.

Em conclusão, pelo prisma de Buckland (1991), cabe à Ciência da Informação o estudo da informação como processo de interpretação, desencadeado pelo sistema de informação a partir de um documento. O produto desse processo Capurro (2003) chama de mensagem e, refletindo sobre a informação como coisa, faz o seguinte comentário:

o valor informativo a que alude Buckland não é uma coisa nem a propriedade de uma coisa, mas um predicado de segunda ordem, isto é, algo que o usuário ou o sujeito cognoscente adjudica a "qualquer coisa" num processo interpretativo demarcado por limites sociais de pré-compreensão que o sustentam.

Infere-se dessa discussão que as mensagens emitidas pelos sistemas de informação apresentam objetividade relativa em relação à recepção. Por mais que os produtos sejam direcionados a uma comunidade específica, no momento da utilização haverá sempre um processo de seleção que é individual e particular. Ou seja: os textos documentários são preparados sob um ponto de vista institucional e, nesse sentido, dependem da aceitação do usuário, no que se refere à sua relevância na solução de questões práticas e/ou de desejos cognitivos.

Para Suzanne Briet (1951, p. 7-9), seguidora de Paul Otlet, a noção de documento aproxima-se da noção de signo: qualquer sinal físico ou simbólico, preservado ou registrado, que pretende representar, reconstruir ou demonstrar um fenômeno físico ou conceitual. Utilizando um antílope como exemplo de documento, a autora demonstra seu pensamento. Na selva, um antílope não pode ser compreendido para nada além do que ele é, ou seja, um animal. Entretanto, no contexto científico, visto como objeto de estudo, adquire lastro de documento, uma vez que constitui uma 
evidência para aqueles que o estudam. Na concepção da autora, a função principal dos documentos é a comunicativa e, nesse sentido, divide os documentos em primários e secundários, ou seja: os artigos escritos sobre um tipo raro de antílope podem ser considerados documentos secundários, na medida em que o próprio antílope (vivo ou em situação arqueológica) é reconhecido como documento primário. Sobre a concepção de documentos secundários, Ortega e Lara (2008, p. 3) esclarecem que a autora

adota a expressão 'produção documentária' para indicar a produção de documentos secundários pelas organizações de documentação a partir dos documentos iniciais (os quais seriam criados pelos autores e apenas conservados pelas organizações de documentação). Considera como documentos secundários as traduções, análises, boletins de documentação, fichários, catálogos, bibliografias, dossiês, fotografias, microfilmes, seleções, sínteses documentárias, enciclopédias, guias de orientação.

O sentido da discussão procura ressaltar o aspecto do conteúdo presente em cada documento, independente de ser um texto composto de palavras ou um objeto, ambos têm a capacidade de prover conhecimento. Qualquer coisa pode ser informativa, o que indica a natureza subjetiva da informação (BUCKLAND, 1991). O que entra em jogo é a questão da interpretação/representação da "informatividade existente nos documentos" (ORTEGA e LARA, 2008, p. 6, 8) por parte dos sistemas documentários e, por parte dos sujeitos receptores, o reconhecimento da "produção documentária" (BRIET, 1951) como informativa.

O que precisa ficar claro neste item é que, no contexto da Ciência da Informação, informação é um conceito que se constrói, conforme o prisma pelo qual é observada, imbricando-se ora no conceito de documento (informação como objeto) ora misturando-se à noção de mensagem (informação como signo). Fundada em valores intelectuais e institucionais, fisicamente, representa-se por meio de determinados padrões documentais que lhe garantem legibilidade, compreensão, possibilidades de transferência e de circulação. Em outras palavras, a informação existe "na harmonia entre forma e substância, mas também entre meio e mensagem, não como texto acabado, mas na perspectiva de interação comunicativa" (ORTEGA e LARA, 2008, p. 8). A respeito da informação documentária, as autoras supracitadas esclarecem que: 
assemelham-se à idéia dos 'documentos secundários' conforme sugeriu Briet. Incluem, hoje, os registros que compõem o sistema documentário no sentido estrito, bem como os produtos documentários derivados, caso das sistematizações feitas pela Ciência da Informação que se aproximam da idéia dos dossiês, de Otlet, combinando dados de diferentes fontes. A atividade documentária desenvolve-se, nesse sentido, a partir da intenção de construir registros que possam ser informativos, considerando não apenas as características extrínsecas do documento original (do autor), como sua possibilidade de recepção (possibilidade de aderência) [...] Observase, no entanto, que a intencionalidade da atividade documentária não implica automaticamente seu uso efetivo traduzido em apropriação (Idem).

No âmbito das informações governamentais, o descompasso entre acumulação e uso da informação vem sendo questionado. Motivada pelas exigências da sociedade atual, pelas facilidades tecnológicas e, sobretudo, por razões econômicas, a noção de documento como acervo estático vem sendo substituída pela consciência de que a informação se realiza na ação da circulação e, nessa ação, contribui com a difusão, revisão, sistematização e criação dos saberes. Neste aspecto é evidente a mobilização do setor público em torno da disponibilização de informações, tanto para o público em geral como para setores especializados. Contudo, a dinâmica que atinge a maior parte das estruturas informacionais do governo privilegia o acesso, bem como a utilização dos novos meios, mas nem sempre observam o tempo (a pretexto dos custos) da construção dos recursos simbólicos que agregam valor à informação, qualificando-a no sentido de mensagem ou de transferência. Obviamente, algumas instituições contradizem essa afirmação porque, além de promoverem a informação como coisas visíveis, enredam-se nos contextos de uso, ou na subjetividade que governa as interfaces com os segmentos usuários, compreendendo que o valor informativo do recurso que disponibilizam não está somente na sua visibilidade, mas no seu alcance social, na sua funcionalidade de responder a uma necessidade humana. Com essa consciência, tratam dos aspectos que envolvem a contextualização da informação, a configuração dos meios de distribuição e o acompanhamento do consumo com a finalidade de aperfeiçoar a oferta em função da demanda. 


\subsection{Informação como signo e a Linguística documentária}

O entendimento da abordagem da informação como signo está na diferença existente entre o conceito de signo e o de sinal, tendo em vista que o processo comunicacional dá-se por meio de trocas simbólicas.

Entendemos por sinal qualquer forma (gráfica, geológica, astronômica, sonora, pictórica, etc.) que não aporta significados intencionais. Mesmo podendo provocar estímulos e/ou reações, os sinais são entidades destituídas de recursos para a construção de significados, ou seja, são eventos que ocorrem sem passar por um processo de convencionalização que propicie representatividade e significação em determinado ambiente cultural. Segundo Edward Lopes (1984, p. 310), “a significação é independente da natureza do significante que a manifesta, se de ordem visual, auditiva ou táctil”, também independe das coisas que são extralinguísticas. Ela é uma construção social ou decorrente da ótica do observador humano, no caso dos chamados signos naturais, por exemplo.

No universo da informação, tais postulados fazem sentido para explicar que o processamento informacional não se dá somente a partir de características físicas do documento ou de um suporte específico. O processamento ao qual nos referimos é a representação de conteúdos que são compostos de signos: mensagens dotadas de significação correspondendo a um domínio específico. Assim sendo, o que estamos chamando de informação pública é ao mesmo tempo produto da representação de uma realidade governamental determinada e de uma possibilidade interpretativa que, embora institucional, também é passível de criatividade.

Quando compreendemos que a informação é um fenômeno humano que acontece na esfera sociocultural, nos distanciamos do paradigma físico, que considera a informação apenas como a troca de sinais (sem compromisso com a relevância na recepção, ou reduzindo-a quantitativamente, como nos estudos que relacionam precision e recall). A concepção da informação como signo refere-se a algo que aporta significação e intencionalidade, uma exclusividade do signo. Em outras palavras, tratase da informação com valor agregado (qualificada para a transferência), isto é, com 
vista a ganhar relevância em um contexto comunicativo especial. O pressuposto básico dessa diferença é o de que a informação é um signo porque traz em si mesmo as condições indispensáveis para sua própria interpretação ou para desencadear interpretantes. Essa possibilidade é garantida pelas linguagens documentárias que, respaldadas nas terminologias de domínio, funcionam como elo entre os conceitos, as representações produzidas e a instância de recepção.

Cientes de que a informação, na condição de entidade ou de processo, configurase por meio da linguagem, vamos abordar a visão saussureana, que, por similitude, nos ajuda a entender as funções da linguagem documentária na constituição da informação documentária, também objeto deste trabalho.

Do ponto de vista estruturalista, a língua é um sistema de valores. No contexto saussureano, os signos linguísticos não unem uma coisa e uma palavra, mas um conceito e uma imagem acústica. Saussure propõe "o termo signo para designar o total, e a substituir conceito e imagem acústica, respectivamente, por significado e significante" (SAUSSURE, 1969, p. 81). As entidades linguísticas só são determinadas no interior do sistema, umas relativamente às outras (...). O valor é, portanto, relacional (LARA, 199, p. 41). “O valor de qualquer termo que seja está determinado por aquilo que o rodeia" (SAUSSURE, 1969, p. 135).

A relação entre significado e significante é arbitrária, no sentido de que o significante é imotivado, não tem nenhum laço natural na realidade, a não ser a convenção estabelecida num grupo linguístico (SAUSSURE, 1969, p. 83).

$\mathrm{Na}$ medida em que a relação entre representação e objeto representado é arbitrária e convencional, os signos passam a ser uma construção da razão e a linguagem o principal instrumento na formação do mundo cultural. É por meio da linguagem que o homem pode ultrapassar o patamar da experiência pessoal e, ao fazer uso de sua consciência, entra em contato com algo que está distante dele.

Os signos são formados de um significado, entendido como marca abstrata, sentido imaterial ou conceito, e um significante, entendido como imagem acústica, 
veículo material dos sentidos, a forma perceptível (letras, imagens, sons, sinais, etc.) que garante a expressão dos significados e a comunicação. Significante e significado vivem em constante relação, são solidários, de maneira que um não existe sem o outro. Segundo Tálamo (1997, p. 5-6),

na ausência de um significado, um significante é simplesmente um objeto, uma coisa qualquer. A significação é algo que deve ser observada a partir do Sistema na qual é gerada. Ela não existe de modo independente e a cada momento é capturada por alguma forma. A significação não se confunde com o referente (a relação existente entre o signo e o objeto real) nem com a representação (aparecimento da imagem mental naqueles que utilizam o signo). O que ocorre é o seguinte: Por força da significação instituída por um sistema de signos, uma espécie de analogia passa a ser estabelecida entre o sistema e aquilo a que se refere (valores subjetivos, relação simbólica). Quando se afirma que a linguagem representa algo, afirma-se que por força da significação ele se propõe no lugar de algo - o substitui.

Na visão de Saussure, um signo só se evidencia em sua singularidade e identidade por ser diferente de outros signos numa cadeia de significação. Aquilo que um signo é só fica estabelecido nessa rede de diferenças. Sua identidade é sempre dependente da diferença. Para o mestre estruturalista, a língua é forma e as unidades linguísticas não são independentes umas das outras, elas pertencem a um sistema (langue) que funciona de maneira relacional. Uma só palavra não comporta significação porque é somente na oposição e contraste com as outras unidades, nas possibilidades de relação com o todo formando um sistema, que as palavras se tornam explicativas, ganhando significação.

A proposta saussureana de estrutura está ligada à idéia de relação no interior do sistema linguístico, à idéia de descontinuidade (sincronia) em relação à própria história da língua, inaugurando a descontinuidade também na ciência moderna. A noção de estrutura foi aprofundada por Greimas sob o argumento de que, para haver sentido, é necessária "a presença simultânea, em nossa mente, de dois termos-objetos ligados por uma relação". Relações conjuntivas são as que acontecem entre dois termos parcialmente idênticos e relações disjuntivas quando a relação implica dois termosobjetos parcialmente diferentes (GREIMAS, 1976, citado por LARA, 1999). 
Nessa ótica, os significados para Saussure e para Greimas são construídos no eixo das escolhas e das combinações, ou seja,

num duplo enquadramento: o sintagmático, discernível no contraste entre elementos discretos in praesentia na parole, e o paradigmático (ou associativo), discernível nas oposições instauradas entre os membros da mesma classe de palavras memorizáveis na langue (LOPES, 1987, p. 235).

Assim, entende-se que

as idéias são contemporâneas das palavras que as exprimem [...] a língua só funciona como instrumento de comunicação quando funciona ao mesmo tempo como instrumento de construção do saber a ser comunicado (LOPES, citado por LARA, 1999, p. 42).

A discussão sobre a representação e linguagem no contexto da Ciência da Informação pode ser sumarizada em duas abordagens-chave que, historicamente, coincidem com o progresso da disciplina. A primeira diz respeito ao uso dos Sistemas de Classificação Bibliográficos, que têm por princípio a organização dos documentos a partir de uma proposta de ordenação do conhecimento elaborada no final do século XIX e início do século XX, cujas "premissas são acumular e reproduzir" (LARA, 1999). Os sistemas CDD e CDU são sistemas de base decimal fundados na classificação do conhecimento de Francis Bacon (memória, imaginação e razão) e nos princípios aristotélicos de inclusão e não inclusão (árvore de Porfírio). Definindo as classes e subclasses a partir das disciplinas canônicas, que são estruturas rígidas, estáveis e universais, apresentam um modelo de organização do conhecimento predeterminado e, consequentemente, uma única forma de representação que não contempla a dinamicidade que caracteriza as transformações que acontecem no âmbito dos saberes. $\mathrm{Na}$ verdade o que se procura assinalar é que esses sistemas classificam os documentos encaixando-os em classificações prontas, sem relevar o conhecimento novo e as estratégias articuladoras presentes nos documentos. Dessa forma, propiciam a análise a partir de um único ponto de vista apresentado como universal.

A segunda abordagem é caracterizada pelo reconhecimento de que as atividades de documentação desenvolvem-se na esfera da comunicação e, nesse sentido, distanciam-se da lógica aristotélica, buscando apoio nas ciências da linguagem para sua 
construção. A idéia de "assunto" pertencente a um único campo disciplinar é superada pela idéia de "tema", que proporciona o relacionamento de diferentes especialidades na sua articulação. O tema “criança", por exemplo, relaciona referencial (conceitos, facetas ou pontos de vista) de disciplinas diversas (saúde, educação, ciências sociais, direito, etc.). A análise realizada privilegia os conteúdos presentes nos documentos e os contextos de uso, pois o objetivo não está mais centrado na preservação e universalidade das representações e sim na organização de informações para atender aos domínios particulares e fins específicos. O compromisso não é com a ordenação em si, mas com a elaboração de linguagens documentárias que façam sentido aos usuários, propiciando a circulação do conhecimento presente nos textos. Nesta direção, considera-se que o sistema documentário resolve as questões sintáticas e semânticas presentes no processo de geração e de recuperação da informação, apoiando-se nas linguagens documentárias, que são instrumentos estruturados com base em um escopo conceitual.

Obviamente, do ponto de vista da evolução da área, essas duas abordagens representam extremos históricos. Entre uma e outra houve uma série de estudos importantíssimos, passando por Ranganathan (teoria das facetas), Foskett (classificações funcionais para a indústria) e Gardin (análise documentária), para destacar os principais atores que processaram a transformação do pensamento da área no que se refere à representação. Na contemporaneidade, anos 90, destaca-se a atuação de "Garcia Gutiérrez, pesquisador espanhol que aborda a questão da representação documentária sugerindo a interface Linguística/Documentação através da proposta de uma Linguística documental e de uma série de pesquisadores brasileiros que exploram os modelos linguísticos" (LARA, 1999, p. 54). Mais recentemente, Garcia Gutiérrez fala da diversidade e do consenso e, em seguida, da desclassificação, outra maneira de operar as interpretações.

Partindo-se do entendimento de que a linguagem documentária é o subsídio vital à existência da informação, tem-se que assinalar que ela é um instrumento que atua em vários momentos da produção e recepção da informação, inclusive fora do circuito de bibliotecas e de sistemas de informação, atingindo a arquitetura de sites e a elaboração de produtos eletrônicos. Sua função principal é dar acesso ao conhecimento existente nos textos, por meio de alternativas de busca que nada mais são do que a difusão 
institucional de escolhas interpretativas ou de proposições iniciais, pontos de partida que contribuem para a geração de conhecimento novo (LARA, 1999, p. 163).

Situada entre a linguagem artificial (de interpretação unívoca) e a linguagem natural dos usuários (de interpretação polissêmica), a linguagem documentária é mais que uma lista de termos coletados sob o critério de garantia literária ou de repetição estatística. Sua configuração pressupõe dar conta de funções externas, relacionadas ao uso, tais como composição de vocabulário, sintaxe (coordenação dos termos) e normalização gramatical e semântica, mas, também, e principalmente, de funções internas referentes à estruturação do sistema nocional, que, apoiado nas terminologias de domínio, possibilita a ancoragem das linguagens documentárias em determinado campo profissional ou científico.

Lara, em sua tese de doutorado (1999, p. 164), sistematiza que os descritores (unidade estruturante da linguagem documentária), reportam-se aos conceitos, mas

não são identificados nem com a palavra e nem com o termo, e sim definidos como unidades mínimas de significação, unidades preferências, signos documentários, unidades semântico-semióticas, interpretantes, signos motivados, unidades de sentido definidas relacionalmente.

O marcante aqui é a diferença existente entre a construção da informação por meio das linguagens documentárias e a construção de conceitos e/ou o uso puro dos termos. A construção dos conceitos acontece em outro nível de análise, no nível epistemológico. Uma explicação clara sobre a designação dos conceitos oferece-nos Machado (2006, p. 151), referindo-se a Michel Foucault, na obra "A arqueologia do saber":

para que os signos verbais existam como enunciado é preciso fixar a relação do enunciado com seu correlato, isto é, com aquilo que ele enuncia. Foucault chama o correlato de referencial e o define como um conjunto de regras que dão existência a um domínio ou campo de objetos possibilitando que determinados objetos possam ser mencionados. 
No nível linguístico, é a Terminologia que trabalha os termos, delimitando os vocabulários dos campos de especialidade, a partir da premissa de que os termos como designação de uma especialidade não estão separados da língua geral, formando outro código, mas, ao contrário, são palavras que estão na situação de termos em função de determinado uso, necessidade de comunicação. A Terminologia procura garantir a comunicação especializada acompanhando o desenvolvimento da prática científica, incorporando e normalizando os novos conceitos gerados pelos domínios do saber, que são designados pelos vocábulos e termos. A Ciência da Informação, por sua vez, também trabalha com o termo/conceito, só que a perspectiva da área é procurar garantir a representação e a recuperação da informação gerada pelo novo conhecimento, expresso nos textos e produtos multimídias, através da construção da informação documentária. Em resumo, enquanto a Terminologia tem por objetivo a transferência de conhecimento, designando e denominando os conceitos, à documentação cabe a transferência das informações produzidas no contexto das especialidades para públicos determinados.

De acordo com Lara (2000), a contribuição fundamental da Terminologia à Linguagem Documentária não está na recolha de termos na literatura e/ou em glossários ou dicionários técnicos, mas,

quando ela se refere aos sistemas de conceitos, às características de uma definição e à identificação das relações entre conceitos. Essa contribuição se reflete através das normas terminológicas particularmente a ISO704 e ISO1087 - como também na literatura teórico-metodológica.

A autora segue argumentando que são as normas terminológicas que permitem ao documentalista trabalhar os termos do ponto de vista conceitual com a finalidade de demarcar campos semânticos, bem como os relacionamentos entre termos e as equivalências semânticas nos tesauros. Entretanto, do ponto de vista pragmático, as soluções de linguagem não estão nesse instrumental, pois, se assim fosse, não haveria paridade entre o aspecto comunicativo e o aspecto conceitual, e a linguagem documentária seria um instrumento sem possibilidades de atualização ou de adaptação às situações reais de uso. 
Do ponto de vista teórico, a Terminologia apresenta duas abordagens. A Teoria Geral da Terminologia (TGT), que, por ser mais voltada à normalização, é mais prescritiva, ou seja, pressupõe a existência de um único termo para designar um conceito, e a Teoria Comunicativa da Terminologia (TCT), proposta por Cabré, que é mais compatível com as operações documentárias. Considerando como base o texto (discurso ocorrência), a TCT trabalha o uso de termos e contextos, admitindo que os sistemas de conceitos variam em sua organização, na medida em que os domínios podem ser abordados de diferentes maneiras. Nas áreas cujo arcabouço conceitual está consolidado, como, por exemplo, nas ciências exatas, ainda se torna possível a relação um conceito para um termo, mas, no campo das ciências humanas e sociais, em que se admite pontos de vistas diferenciados sobre um mesmo objeto ou fenômeno, nem sempre é possível manter a monossemia.

Voltando às estruturas, Lara (1999, p. 60-66) postula que a noção proposta por Saussure e aprofundada por Greimas oferece parâmetros para construção dos vocabulários para fins documentários. As unidades de um conjunto vocabular relacionam-se umas com as outras a partir de um ponto de partida inicial, selecionado como pertinente para articular determinados objetivos informacionais e institucionais, formando, nesse plano de representação, arranjos puramente relativos em relação a outros arranjos possíveis. Internamente, a linguagem documentária também se define na oposição estabelecida entre seus elementos. Primeiramente, estrutura-se opondo descritores e não-descritores. Depois, entre os descritores, a posição de cada um deles é definida em relação aos demais que com ele formam um sistema por meio do estabelecimento de relações lógicas (de conjunção e disjunção) e associativas. Essas relações são baseadas na identificação de características de semelhança e de diferença a partir do estabelecimento de um eixo semântico principal, que define a interpretação que se deve ter do conjunto (do sistema). Nessa rede de significação que se constrói, a parte (utilizando pelo menos uma característica calcada na diferença) define o todo na sua extensão, sendo que a compreensão de cada parte configura-se em uma estrutura completa em si mesmo, integrante do eixo semântico principal. Definidos os vértices a partir de hipóteses de organização realizadas com base em inferências terminológicas, de uso e de função no sistema informacional, é possível apoiar horizontalmente os termos abrindo-se novas possibilidades de articulação. 
Uma questão polêmica que divide os pesquisadores na atualidade diz respeito à questão da semiose ilimitada. Esta questão, para alguns, desemboca no controle do vocabulário ou da significação, ou seja, na mediação como signo estabilizado, que tem referência nas terminologias de área. Para outros, a descrição dos assuntos deve seguir de maneira descontrolada, no "universo aberto de interpretação da linguagem natural, que têm seus benefícios porque não solicita o aprendizado de regras de funcionamento, tem seus problemas em relação à especificidade da recuperação” (LARA, 2006a).

Para a Ciência da Informação, a capacidade dos signos documentários de impulsionar o conhecimento depende da qualidade da linguagem documentária adotada. Tal afirmação quer dizer que a representação é um processo de codificação de conteúdos, que, para alcançar a condição de informação documentária, tem que ser decodificada, isto é, compreendida enquanto oferta de sentidos na instância da recepção. Informações documentárias são mensagens, pois referem-se ou correlacionam-se com algum sistema como entidade física e conceitual.

\subsection{A interação com os usuários}

Interpretar supõe uma construção de sentidos, uma troca retroalimentada entre as proposições oferecidas pela instância de produção e as formas como os usuários manifestam suas necessidades no momento da busca. O que se convencionou chamar, modernamente, de acesso é uma situação de comunicação complexa que envolve uma rede de fatores de ordem linguística, cognitiva, sociocultural e interacional. O que se quer expressar é que, assim como o signo documentário (LARA, 1999), que, como substituto do texto original, não consegue representá-lo na sua totalidade, as formas de mediação de sentido (LD, interfaces de sistemas) também não são completas. Segundo Lara (1999, p. 142), às vezes, elas são insuficientes para controlar, sozinhas, o processo de recuperação, pois “cada usuário estabelece, a seu modo, uma formulação baseada na sua experiência colateral e nas suas necessidades particulares". Assim sendo, quanto mais a fonte produtora conseguir explicitar e qualificar as representações oferecidas, mais chance os usuários terão de recuperar documentos/informações relevantes e pertinentes aos seus propósitos. A linguagem documentária tem que apresentar 
coerência nas relações que engendra, de forma que as mediações resultantes sejam reconhecidas pelos pesquisadores do campo de estudo em pauta.

A linguística textual, desde a década de 80 , vem colocando a questão da coerência adotando uma perspectiva pragmática de grande valia para os estudos da documentação (LARA e TÁLAMO, 2007, p. 6, 7, 12, 13). O argumento é que a coerência constrói-se em dada situação de interação, entre o texto e seus usuários. $\mathrm{Na}$ concepção de base pragmática, o texto é concebido como ato de fala,

já não se trata de pesquisar a língua como sistema autônomo (estruturalismo Saussureano), mas, sim, o seu funcionamento nos processos comunicativos de uma sociedade concreta (...) os textos deixam de ser vistos como produtos acabados de uma ação discursiva que devem ser analisados sintática ou semanticamente, passando a ser considerados elementos constitutivos de uma atividade complexa, como instrumentos de realizações de intenções comunicativas e sociais do falante (...) o ouvinte não se limita a entender o texto, no sentido de captar apenas o seu conteúdo referencial, mas necessita, isto sim, reconstruir os propósitos comunicativos que tinha o falante ao estruturá-lo, isto é descobrir o 'para quê' do texto" (KOCH, 2006, p. 13-15).

Citando Schmidt, a autora reforça a abordagem:

A linguagem... já não é considerada primariamente um sistema de signos, denotativo, mas um sistema de atividades ou de operações, cuja estrutura consiste em realizar, com a ajuda de um número aberto de variáveis e um repertório fechado de regras, determinadas operações ordenadas, a fim de conseguir dado objetivo, que é a informação, comunicação, estabelecimento de contato, automanifestação, expressão e (per)formação da atividade (Idem, p.16)

Com foco na coerência, Chorolles, também citado por Koch (2006, p. 20), a eleva à condição de "princípio de interpretabilidade do discurso, postulando que não existem sequências de enunciados incoerentes em si, visto que, numa interação, é sempre possível construir um contexto em que uma sequência aparentemente incoerente passe a fazer sentido".

Ressaltando os aspectos cognitivos do processamento da informação, Koch (2006, p. 21-33) reúne referências fundamentais à documentação. Explica os quatro grandes sistemas de conhecimento acionados na produção e recepção de informações: 
O linguístico - Conhecimento gramatical e léxico, responsável pela articulação som/sentido.

O enciclopédico, semântico ou conhecimento de mundo - É aquele que está armazenado na memória de cada individuo. Adquirido pela experiência social, serve de base aos processos conceituais. Determinados socialmente, os modelos cognitivos são representados na forma de redes, nas quais os conceitos são concebidos como variáveis que denotam características estereotípicas e que durante os processos de compreensão são preenchidas com valores concretos. Segundo Van Dijk, após uma série de experiências do mesmo tipo, os modelos vão se generalizando, com a abstração das circunstâncias específicas. No processamento da informação, selecionam-se os modelos com a ajuda dos quais o estado atual de coisas pode ser interpretado. As unidades não explícitas no texto são inferidas do respectivo modelo. Na falta da informação explícita em contrário, utiliza-se como preenchedor (filler) a informação estereotípica (standard).

O interacional - É o conhecimento sobre as ações verbais (formas de interação através da linguagem). Englobam os conhecimentos do tipo ilocucional (permite reconhecer os objetivos do falante em dada situação de interação), comunicacional (quantidade de informação necessária, seleção de variantes adequadas e tipo de texto), metacomunicativo (conhecimento sobre os vários tipos de ações linguísticas).

As estruturas ou modelos textuais globais - Permitem ao falante reconhecer textos como exemplares de determinado gênero ou tipo. Envolvem o conhecimento das macrocategorias que marcam os diversos tipos de texto, sua ordenação ou sequenciação, conexão entre objetivos, bases textuais e estruturas globais.

A mobilização dos diversos sistemas no processamento da informação mostra que o processamento textual é uma prática estratégica e tais estratégias são cognitivas, sociointeracionais e textualizadas. Van Dijk (citado por KOCH, 2006, p. 26) explica:

as estratégias são hipóteses operacionais eficazes sobre a estrutura e o significado de um fragmento de texto ou texto inteiro. Utilizando informação ainda incompleta, o usuário da língua pode chegar a uma interpretação - a informação é processada online.

Assim, o processamento da informação depende não só das características do documento como também de características do usuário da língua, ou seja, de seus objetivos, de suas convicções e de seu conhecimento do mundo. Na perspectiva pragmática, o uso determina o sentido dos termos. 
Desde o início de nossa argumentação buscamos sintonia com os autores que explicitaram ser a informação, do ponto de vista da produção, um corpo físico e conceitual (uma mensagem), consolidado no processo comunicativo. A relação entre informação e materialidade prende-se na permanência. Qualquer ato de fala, oral ou escrito, qualquer declaração, observação, dedução, diálogo, interpretação, etc. são informativos e dependentes de formatos e padrões que são expressões de nossa intencionalidade no tempo e no espaço. $O$ avanço tecnológico interfere nessa construção. As tipologias documentais e os gêneros tradicionais, em ambiente eletrônico, são diluídos. A máquina opera com código próprio, ou seja, a materialidade transforma-se em energia, são bits e não mais livros, discos, fotos, poesia ou romance. Os objetos reais são transformados em objetos digitais e as diferenças (intrínsecas e extrínsecas) existentes entre eles também são descritas/escritas a partir desse código.

Partindo-se do pressuposto de que a informação é uma mensagem porque leva consigo significados interpretáveis na instância de recepção, essa codificação tem que funcionar não apenas como sinal, mas atingir o patamar semântico-pragmático sem o qual a comunicação não se realiza. Para atingir as estruturas textuais, vários elementos concorrem.

Na opinião de Pérez Tornero, em primeiro lugar, a informação já não se fixa a partir da tecnologia de imprensa, mas por meio de

uma nova escritura icônica que intenta cumprir as mesmas funções
que a alfabética, fragmentando o contínuo de uma representação,
esquematizando até evidenciar as estrutura dessa representação e
permitindo a abstração da idéia a partir da imagem (PÉREZ
TORNERO, 2000, p. 78-80, citado por RODRÍGUEZ BRAVO, 2002,
p. 160).

Essa estrutura digital ou formato é chamado de hipertexto ${ }^{6}$. Ele rompe com a linearidade da apresentação do documento impresso ou com a estrutura sequencial da

\footnotetext{
${ }^{6}$ Por hipertexto entendemos a configuração de rede, nós se relacionando com outros nós numa sequência que pode tender ao infinito. Apoia-se em uma linguagem de informática (ASCII American Standard Code for Information Interchange), adaptada a um formato ou um padrão de apresentação de mensagens (HTML - Hyper Text Markup Language) e um protocolo de transmissão (HTTP - Hyper Text Transfer Protocol).
} 
informação, permitindo que a leitura do documento seja guiada pelas nossas indagações e associações mentais. Suporte e conteúdo não são mais vistos como categorias dependentes. Os suportes perdem relevância e o que se manipula a partir de então são os conteúdos informativos, que se recuperam, se relacionam, se transferem, se copiam e são usados remotamente. (RODRÍGUEZ BRAVO, 2002, p. 168).

Em segundo lugar, esse documento digital multimídia, em que convivem texto, imagem e som, unifica tecnologicamente os diferentes canais de expressão informativa. Assim sendo, as principais mudanças que a tecnologia proporciona são correlacionadas com o suporte, com o canal, com o código, com a organização das informações e, sobretudo, com a maneira como usuários e informação interagem.

Segundo Lara e Tálamo (2007, p. 3, 4)

o papel da Ciência da Informação, nas situações referidas, tem normalmente se relacionado à construção e disponibilização de "filtros" para orientar a busca e a recuperação, inspirados largamente na garantia literária, com recurso à terminologia de área, e na garantia de uso, ainda incipiente em termos de metodologias eficientes para sua elaboração. Embora, como afirma Gutiérrez, "Evadir-nos da classificação, ou afastarmo-nos, mesmo que um passo, é tão utópico como querer fugir da linguagem ou do pensamento" (GARCIA GUTIÉRREZ, 2006), permanece a dúvida não só no que tange à escolha entre os modelos classificatórios, mas também, e principalmente, ao grau de adequação dos mesmos à função e objetivos da Documentação, qual seja, organizar conteúdos para viabilizar sua circulação, acesso e uso.

A internet é um recurso que multiplicou exponencialmente o número de textos técnico-científicos disponíveis. A facilidade de publicar e a possibilidade da mesma informação em diferentes formatos congestionam a rede e tornam a triagem do material relevante uma tarefa difícil. Para Gardin (2001), a facilidade de acesso está relacionada à própria edição do recurso informacional, que deve ser preparado utilizando-se das vantagens tecnológicas em formatos voltados mais para a consulta do que para a leitura. A lógica que governa o meio digital não é tipográfica, é cognitiva, e, assim sendo, os textos devem distinguir os seus elementos estruturais informativos (os raciocínios que sustentam a construção do conhecimento) e não a retórica. As partes do documento que o autor considera mais expressivas em termos de conteúdo (dados empíricos e 
hipóteses, argumentação ou conclusões relacionadas) têm que estar evidenciadas, funcionando como esquema de acesso para poderem ser ativadas pelo leitor quando necessário, e rapidamente, sem que se tenha que ler o texto inteiro. Portanto, a filtragem (do que é informativo) é uma atividade organizativa que envolve seleção, análise, síntese e juízo de valor, isto é, a representação das intenções do emissor relacionadas a situações específicas de uso.

Gardin (2001) expressa textualmente que a operacionalização desse processo demanda a competência de bibliotecários e documentalistas na construção do que pode ser chamado por nós de rotas de consulta. Rotas de consulta são estruturas classificatórias, propostas de navegabilidade, enlaces entre pontos de informações usados entre textos na web, mas, também, proposta de arranjo para produtos eletrônicos, como um CD-ROM, por exemplo. Para o autor, os meios de difusão tradicionais, tais como os boletins de disseminação seletiva da informação, os alertas correntes, os resumos e boletins bibliográficos reproduzidos na internet com outros nomes, são válidos, mas não suficientes para manter o usuário em dia com a literatura técnica e científica que cresce a "passos largos". A questão não é somente saber da existência da publicação, mas, principalmente, achar tempo para lê-las.

Em nossa opinião, a tipologia dos meios que possibilitam a comunicação técnico-científica faz grande diferença na solução do desequilíbrio (produção científica versus leitores) colocada pelo autor. Uma revista eletrônica se propõe a um tipo de difusão muito diferente de um repositório, de uma biblioteca digital, de um índice ou CD-ROM. Gardin (2001) refere-se ao baixo consumo dos artigos científicos e de outras traduções, propondo sua re-escrita em formatos condensados, mais adequados à assimilação do que, por exemplo, a digitalização de originais ou equivalentes. Os textos têm que estar acessíveis para consulta, mas isto não quer dizer que basta serem digitalizados, eles têm que ser estruturados aproveitando os recursos proporcionados pelos meios eletrônicos, ao invés de serem disponibilizados na íntegra ou noticiados (com volta para original), como se fez na superação da crise passada, cuja principal causa era a deficiência de comunicação. 
Hoje o problema é como racionalizar o tempo de leitura e, segundo Gardin (2001), a solução corresponde à configuração de uma nova estratégia de comunicação científica fundada na seleção e fragmentação lógica dos conteúdos (conteúdos proposicionais e resultados), na condensação textual (reescrita dos raciocínios), na tematização (árvores propositivas), em resumo, em um formato ou padrão (chamado pelo autor de "esquematizações logicistas") que funcione de maneira a comunicar idéias e sentidos, atentando para a preservação do conteúdo, mas, principalmente, para o comportamento consultivo e tempo de leitura do usuário.

A título de exemplo, apresentamos a seguir o esquema lógico do CD-ROM "Estudo sobre as pérolas de Cornalina", elaborado pelo autor. O esquema mostra as possibilidades de leitura desenvolvidas e os elementos referenciais que auxiliam o leitor no entendimento da obra e na seleção de conteúdos que podem ocorrer em momentos descontinuados.

Figura 7 - O esquema do CD-ROM "Estudo sobre as pérolas de Cornalina", por Gardin

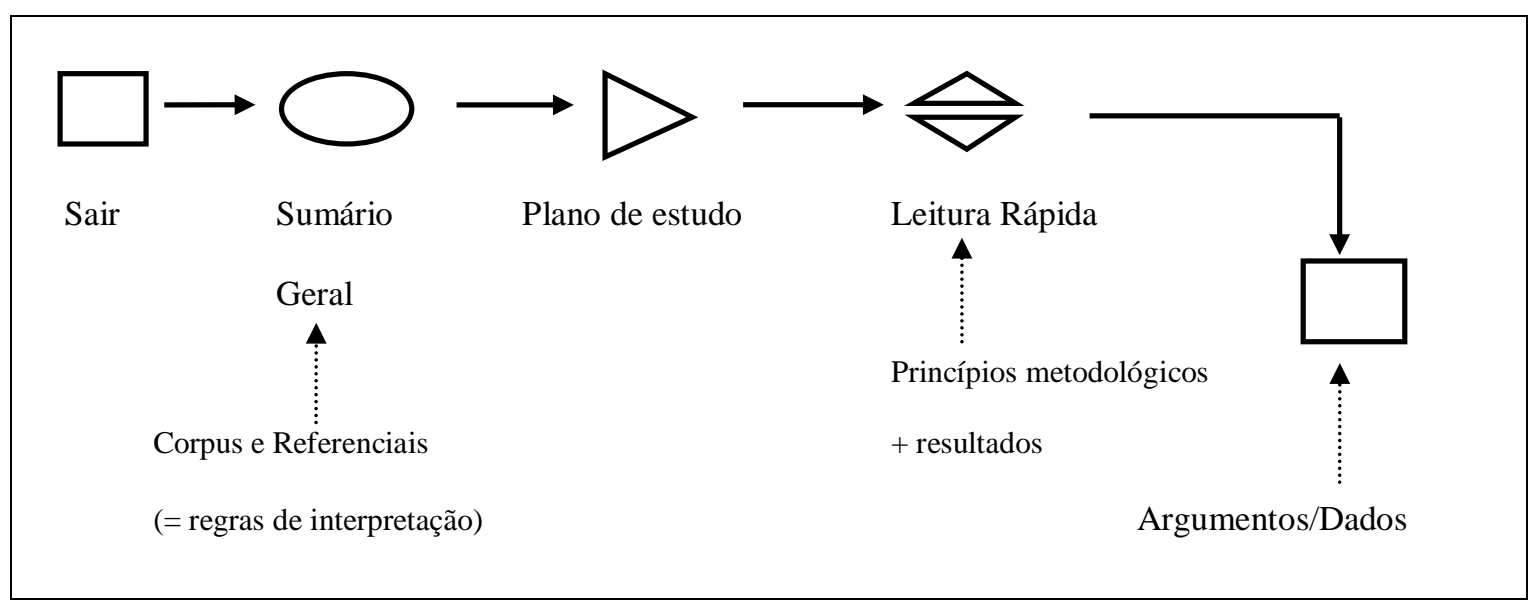

\footnotetext{
${ }^{7}$ Reproduzimos o esquema do autor apresentado em sala de aula pela Prof ${ }^{\mathrm{a}}$ Johanna Smit, em 2007.
} 
Lara e Tálamo, na conclusão do trabalho "A recepção no processo documentário: informação e produção de sentido" (2007, p. 13), referem-se à carência de estudos que incorporem características relevantes do usuário à estrutura da mensagem, procurando solucionar a questão da interação, isto é, fazem referência ao distanciamento (ainda existente) entre as instâncias de produção e de recepção:

De fato, acredita-se que uma vez disponível a informação e concebidos os usuários como um conjunto de classes etárias, de sexo, de profissão, etc. resolve-se a questão dos fluxos sociais de informação. Esse é o contexto da cultura de massa e não o da cultura da informação assentado no valor do conhecimento e da informação. É preciso ir além e buscar no modo pelos quais os vários segmentos sociais desenvolvem as relações informais e suas práticas elementos para a composição de filtros sociais mais integrativos. Nesse sentido as formas de acesso cognitivo à informação ganham destaque, uma vez que exigem a construção de redes, metáforas das interações que vivem. Jamais se ignorou que o usuário vivesse em grupos com interesses formulados de forma específica, com fontes de informação próprias, etc. Supunha-se apenas que nada disso tinha importância para o funcionamento dos fluxos de informação. Hoje se discute como integrar esses componentes ao processo documentário, já que nenhum de seus elementos isolados garante o uso efetivo da informação. 


\section{AS EXPERIÊNCIAS PARA A TRANSFERÊNCIA DA INFORMAÇÃO DAS INSTITUIÇÕES PÚBLICAS: as práticas informacionais da Fundação Prefeito Faria Lima - Cepam}

este capítulo pretendemos verificar o desempenho da Fundação Prefeito
Faria Lima - Cepam e avaliar suas contribuições para o estabelecimento da comunicação documentária generalizáveis para outras instituições governamentais semelhantes.

Em fase de reestruturação, o Cepam está revendo os princípios norteadores de sua prática de trabalho com base na constatação de que o trabalho não manual é fundamentalmente conversacional e, em decorrência, as instituições são redes dinâmicas de conversações e seus funcionários agentes conversacionais ${ }^{8}$. Com missão relacionada à capacitação dos municípios paulistas, atua por meio da prestação de assistência técnica, da realização de cursos e seminários, de publicações e da difusão de informações técnico-políticas. Sob os desígnios dos atuais dispositivos de circulação e distribuição da informação, o órgão volta-se para um padrão de atendimento que inclui a web. Seu site está em aperfeiçoamento para atender a quatro campos de interesses: institucional; assinante Cepam (com serviço de perguntas e respostas); conhecimento (com divulgação da produção interna na área de políticas públicas, informações de outras entidades que se dedicam às questões congêneres e a biblioteca) e campo de interatividade, no qual pretende desenvolver aplicativos de alimentação conjunta com os municípios e outros parceiros.

Nesse tipo de decisão (comunicação a distância) o estágio informacional dos municípios conta muito, pois são eles os receptores que estão na outra ponta do

\footnotetext{
${ }^{8}$ Entendimento extraído do curso "Desenho de Conversas nas Instituições: a comunicação no cotidiano", ministrado por Heloisa Nogueira e Klaus Schubert nos dias 7, 8, 9, 29 e 30 de maio de 2008, no contexto das atividades de Planejamento Estratégico realizadas pelo Cepam. Um dos resultados previstos pelo curso foi a compreensão da importância da linguagem e das conversas cotidianas, ou seja, entender o próprio trabalho como um conjunto de conversações que podem ser desenhadas.
} 
processo de comunicação. Se as necessidades de informação dos municípios mudam, a instituição prestadora de serviços deve acompanhar a transformação; em contrapartida, se a instituição prestadora de serviço altera o modo de distribuição e de oferta de informações, os municípios usuários têm que ser inseridos nessa mudança. No contexto do paradigma tecnológico, as empresas públicas priorizam ações internas relacionadas à provisão dos meios físicos (necessários), a despeito de perderem (por um tempo) espaço no mundo informativo, que é externo e dependente da oferta de informações. Ou seja, enquanto o governo se aparelha, os estoques existentes (sem incentivos) podem ficar à deriva, correndo o risco de se transformarem em excedentes. Esta talvez seja uma contradição contemporânea: a informação, para existir no novo regime informacional, precisa ser reelaborada e para isso necessita de regras e, principalmente, de direcionamento político-institucional sobre os "meios, os recursos preferenciais, padrões de excelência, arranjos organizacionais de seu processamento seletivo, dispositivos de preservação e distribuição a serem utilizados" (GONZÁLEZ DE GÓMEZ, 2004, p. 34).

O Cepam, no espírito de promover uma política de informação que considera a informação como parte de um processo de negociação de sentido, envolvendo dados da produção (estoques organizados, interface de acesso) e da recepção (integração de referenciais de conhecimento e necessidades do usuário), procura utilizar a tecnologia como apoio e não como substituta de suas conversas e atribuições. Na construção do cenário dessa política, identificamos quatro práticas de geração de informações que divulgam o ponto de vista institucional junto aos municípios:

1. Geração de informações com a finalidade de responder factualmente às dúvidas de ordem legal e técnica por meio do serviço de perguntas e respostas jurídicas.

2. Geração de informações para capacitação da gestão pública e implementação de políticas públicas por meio da elaboração de publicações impressas ou digitais e da constituição de observatórios digitais de acompanhamento de políticas setoriais em âmbito global. 
3. Geração de informações de interesse estratégico dos municípios e sobre os municípios, disseminadas pelo site, no formato de notícias, artigos completos, informações político-eleitorais, relato de experiências, estatísticas, etc.

4. Geração de informação para acesso à produção documental da instituição e à documentação recebida de fontes diversas armazenadas na biblioteca.

Cada prática tem objetivos relacionados com a ação que pretende impulsionar e, em função disso, é capitaneada por especialistas diferentes, incluindo os profissionais da informação. Os especialistas, dentro de seu universo temático, identificam, processam, interpretam e socializam suas descobertas, observações, análises e sistematizações empíricas e teóricas em formatos diversos. Os bibliotecários e documentalistas, porque têm seu núcleo de interesse e de competência relacionado à comunicação dos “conteúdos" dos documentos criados pelos especialistas, não são preparados para interpretar no sentido do julgamento do conhecimento que o município mais precisa. $\mathrm{O}$ papel da área é lidar com toda a documentação, filtrando informações (a partir de critérios pragmáticos) e gerando instrumentos, formatos e padrões específicos (documentos secundários), na perspectiva de operacionalizar a política de informação da organização em qualquer dos setores especificados.

Esclarecemos que entendemos por critérios pragmáticos aqueles oriundos da experiência e da interação mantida com os usuários e com as áreas de atividades. Isto não quer dizer que eles sejam extraídos somente da demanda recebida, antes, são baseados no potencial de uso que se acredita existir ou que se tem interesse em criar. Critérios pragmáticos incluem feelings e correspondem ao conhecimento tácito dos profissionais que atuam diretamente na gestão da informação, fazendo a mediação entre os textos, o discurso técnico-científico, os objetivos e metas institucionais e os interesses de seus usuários. Dito de outro modo, o conhecimento proveniente da ação de informar, ou seja, da ação comunicativa que se estabelece entre a emissão e a recepção (por exemplo, saber o que os usuários mais solicitam, o que pensam sobre determinadas questões, quais são seus problemas cognitivos ou suas necessidades informacionais, como solicitam, que linguajar utilizam, termos preferenciais, nível de profundidade do pedido, para que solicitam, com que urgência, com que periodicidade, em que formato 
preferem receber a informação, se abrem e-mail, consultam sites, acompanham blogs, etc.), tem que ser tão determinante quanto outros aspectos constituintes da informação, na medida em que cabe a ele responder o "para quê" da informação (KOCH, 2006, p. 15). Com status de filtros, os critérios pragmáticos são aplicados na seleção de conteúdos e na organização da informação em formatos e meios mais favoráveis às situações de uso. Acreditamos que a perspectiva pragmática é a única que pode colocar, de fato, a informação em circulação porque cria fluxos, formatos e dinâmicas de oferta e uso, isto é, cria o contexto comunicativo-situacional necessário para que as proposições do sistema documentário (os sentidos) sejam reconhecidas como informação pelos usuários.

Assim sendo, os critérios pragmáticos realizam objetivos funcionais. Eles são intencionais, processuais e viabilizam as estratégias de organização e de divulgação da informação com a finalidade de atingir o usuário. Eles estão presentes na construção de sistemas de informação, na elaboração de documentos de divulgação, na arquitetura de sites, na racionalização dos observatórios e assim por diante. Trazer o usuário para dentro do processo de produção é produzir mensagens mais próximas de seu universo e quebrar as barreiras que os meios e os canais de distribuição porventura possam representar. Produzir mensagens com valores agregados capazes de mobilizar os diversos sistemas interpretativos do usuário $(\mathrm{KOCH}, 2006$, p. 22-25) é fundamental para alcançar os propósitos e intencionalidades desejadas. A divulgação de glossários e, às vezes, a discussão dos conceitos pertinentes a uma área de atividade, porque temos tecnologia simples capaz de proporcionar essa interatividade, é uma maneira de compartilhar com o usuário a construção da informação.

No âmbito da Ciência da Informação, a noção de filtragem relaciona-se à informatividade (potencialidade de ser informativo para alguém) e à sua vinculação com objetivos utilitários de ordem institucional e intelectual. Portanto, critérios pragmáticos orientam a filtragem e a organização no sentido da função da informação, das suas possibilidades de oferta e de compartilhamento com a comunidade do domínio focalizado. Em síntese, são os princípios pragmáticos que sustentam a comunicação entre a emissão e a recepção, isto é, permitem que um potencial informativo (um sentido caracterizado por uma orientação temática) seja relacionado a um contexto 
comunicativo identificável, de modo a levar a uma atuação prática desejável (científica, técnica especializada, política, social, etc.). Para isso, os diversos discursos envolvidos na ação comunicativa (do sistema enunciador, dos usuários, dos autores produtores de textos e o da área de atividade) são relacionados entre si criando as regras de interpretação necessárias para compreensão e utilização da informação. Segundo Koch (2006, p. 19), “a coerência não se estabelece sem se levar em conta a interação, bem como as crenças, as normas e os valores dos interlocutores".

No contexto da produção da informação como mensagens significativas, as decisões institucionais contam muito, pois é esperado que elas (as decisões) se transformem na política de seleção e de processamento, já que a área opera com os processos simbólicos (valores). Nesse sentido, a geração de informação no espaço de uma organização não deve ser constituída de ações absolutamente independentes. É recomendável que os produtos sejam derivados de um esforço proporcionado pela troca de conhecimentos e pela integração de diferentes habilidades. Especialistas e profissionais da informação são os operadores da política informacional da organização, são os arquitetos e construtores da informação difundida. Nas palavras de Tálamo e Smit (2007, p. 54), hoje, a "noção de sistema não mais como a reunião de ações, mas de atores" é que dá sentido verdadeiro à interdisciplinaridade, fazendo dela uma estratégia segura de abordagem de objetos e de processos complexos, tais como a construção de sistemas significantes que permitam oferecer informação qualificada para acesso, uso e circulação do conhecimento. Essa afirmação pressupõe o desafio contemporâneo, de natureza disciplinar e pragmática, isto é, experimentar os meios (formatos e padrões) de trazer as características do usuário para dentro do processo de emissão de mensagens, criando a verdadeira interatividade.

\subsection{A base de dados de pareceres jurídicos}

Neste item, vamos descrever as ações desenvolvidas sobre a coleção de pareceres jurídicos. Nossa escolha se justifica no fato de que a coleção serve de exemplo de como um conjunto de conhecimentos registrados e estocados pode ser explorado do ponto de vista de seus valores informativos, vindo a compor um fluxo de informações mais ou menos estável, considerando os regimes histórico-sociais. 
Entendida como meio e como signo, a documentação (da monta de 27.000 documentos) é reutilizada na elaboração de novos pareceres e consultada por um público heterogêneo que nem sempre é formado de especialistas.

A elaboração do texto do parecer é atividade da área jurídica, que recebe as demandas dos municípios na forma de uma pergunta, estuda o problema, discute diretamente com os interessados e emite uma orientação por escrito com uma solução. A documentação gerada é encaminhada para a biblioteca, que funciona como "depósito legal" e memória institucional, cabendo a ela a organização física da coleção e o processamento em base de dados, tendo em vista a construção das vias de acesso à coleção.

A base de dados foi desenvolvida em winisis e funciona de forma referencial, registrando cada unidade documental do ponto de vista de seus atributos (autor, $\mathrm{n}^{\mathrm{o}}$ de parecer, processo, ementa, assunto, município solicitante, data, etc.), de forma a permitir recuperar o parecer original. Na época em que foi implantada, a aplicação representou um reforço às atividades do órgão, pois, uma vez organizada, a biblioteca podia oferecer os pareceres como alternativa de atendimento. Muitas das incertezas dos usuários municipais foram resolvidas e ainda o são no âmbito da biblioteca através da consulta à essa documentação.

No concernente à recuperação temática dos documentos, a indexação e a ementa fazem a condensação do documento original. Os termos atribuídos promovem o acesso aos originais, enquanto que a ementa, fazendo papel de resumo, fornece os elementos adicionais para que o usuário, na seleção, possa decidir quais documentos se aproximam mais de suas necessidades.

A área jurídica não respeita um padrão terminológico na elaboração dos documentos, apesar do uso da linguagem especializada. Os termos empregados pelos advogados apresentam variações, mesmo dentro de um campo temático. Assim sendo, a análise documentária procura controlar a dispersão, produzindo representações mais qualificadas que diminuam recuperações equivocadas e/ou desinformação na recepção. 
A linguagem documentária é o instrumento que permite essa operação, na medida em que tem por objetivo aproximar o conhecimento do público usuário. Como instrumento de significação, ela fornece as bases interpretativas para que a codificação da mensagem (ou a informação) seja compreendida na instância da recepção.

A linguagem documentária como instrumento mediador desse conjunto documental foi concebida antes de sua aplicação. Com base em metodologia específica, ela propõe uma estrutura conceitual, ou seja, um modo de organização que contemple a linguagem especializada, o vocabulário usado nos textos dos pareceres e a linguagem natural dos usuários, de forma a compor um arranjo significativo.

Apresentamos nas páginas seguintes a representação gráfica e alfabética de um extrato da categorização com vínculos realizada para o tema Servidor Público. Os vínculos mostram as relações conceituais fixadas em torno do tema.

Figura 8 - Categorização como vínculo

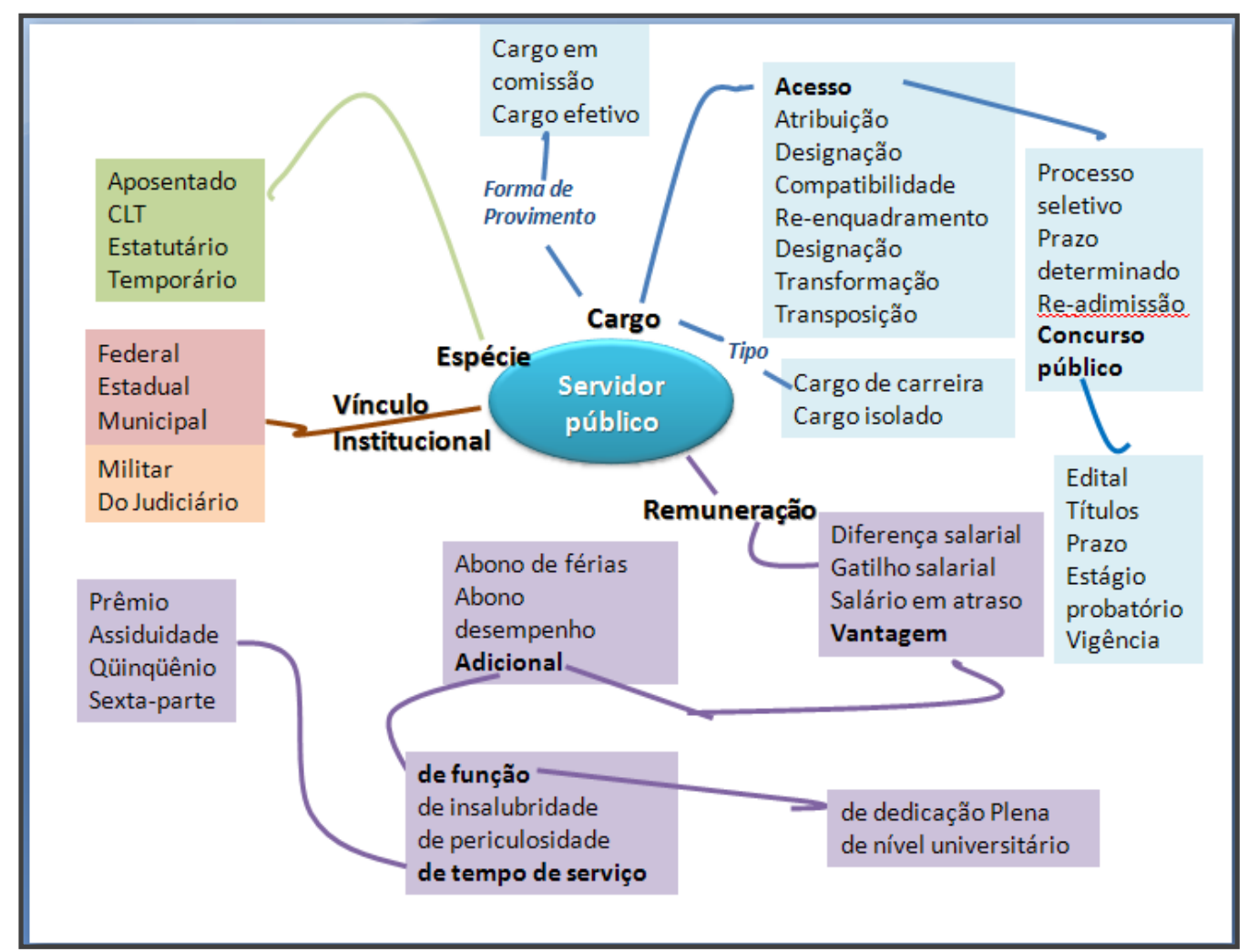


Figura 9 - Abordagem alfabética estruturada da categorização como vínculo

\begin{tabular}{|c|c|}
\hline $\begin{array}{l}\text { ACESSO } \\
\text { TE Concurso público } \\
\text { Processo seletivo } \\
\text { Prazo determinado } \\
\text { Readmissão } \\
\text { ADICIONAL } \\
\text { TE Adicional de periculosidade } \\
\text { Adicional de insalubridade } \\
\text { Adicional de função } \\
\text { ADICIONAL DE FUNÇÂO } \\
\text { TE Adicional de dedicação plena } \\
\text { Adicional de nível universitário } \\
\text { ADICIONAL POR TEMPO DE SERVIÇO } \\
\text { TE Prêmio assiduidade } \\
\text { Quinquênio } \\
\text { Sexta-parte } \\
\text { TE Acesso } \\
\text { Atribuição } \\
\text { Designação } \\
\text { Compatibilidade } \\
\text { Reenquadramento } \\
\text { Tipo (de Cargo) } \\
\text { Forma de provimento } \\
\text { TE Edital } \\
\text { Estágio probatório } \\
\text { Prazo } \\
\text { Títulos } \\
\text { Vigência }\end{array}$ & $\begin{array}{l}\text { ESPÉCIE (de Servidor) } \\
\text { TE Aposentado } \\
\text { CLT } \\
\text { Estatutário } \\
\text { Temporário } \\
\text { FORMA DE PROVIMENTO } \\
\text { TE Cargo em comissão } \\
\text { Cargo efetivo } \\
\text { REMUNERAÇÃO } \\
\text { TE Diferença salarial } \\
\text { Gatilho salarial } \\
\text { Salário em atraso } \\
\text { Vantagem } \\
\text { SERVIDOR PÚBLICO } \\
\text { TE Cargo } \\
\text { Espécie } \\
\text { Remuneração } \\
\text { Vínculo institucional } \\
\text { TIPO (de Cargo) } \\
\text { TE Cargo de carreira } \\
\text { Cargo isolado } \\
\text { VANTAGEM } \\
\text { TE Abono de desempenho } \\
\text { Abono de férias } \\
\text { Adicional } \\
\text { TE Federal } \\
\text { Estadual } \\
\text { Municipal } \\
\text { Militar } \\
\text { Do Judiciário } \\
\text { VINCULO INSTITUCIONAL } \\
\text { Tele }\end{array}$ \\
\hline
\end{tabular}

Com a linguagem documentária, a biblioteca credenciou-se para atender os dois tipos de público:

- Internamente, as solicitações da própria área jurídica, que reutiliza os pareceres emitidos como subsídio na prestação de novos atendimentos;

- Externamente, atendendo preferencialmente os municípios, que fazem suas solicitações presencialmente, por ofício, e-mail e telefone, e ao público em geral.

No atendimento ao público externo, quase sempre a mediação do bibliotecário é fundamental. Não raras vezes, o usuário tem dificuldade em expressar o problema para o qual procura uma solução. Suas razões são diversas, variando desde as dificuldades de 
operar com a tecnologia, até por razões cognitivas e semânticas relacionadas ao entendimento (ou discordância) da linguagem fixada pelo sistema documentário para a recuperação da informação. Segundo Araújo (1999, p. 156, sobre DU CERTAU, 1994), tais questões demonstram que "o sujeito receptor seleciona", confirmando sua postura de "ser pensante ativo" integrante do fluxo informativo.

Os meios de comunicação, especialmente e-mail e telefone, são os principais colaboradores do atendimento que não seja presencial. Rompendo os limites de espaço e de distâncias, eles viabilizam as conversações com o usuário, promovendo a interação capaz de agregar valor ao processo de seleção e transferência da informação. Uma solicitação por e-mail nem sempre fornece as pistas suficientes para que a informação esperada seja provida adequadamente e, assim sendo, as conversas com o receptor têm que continuar até que se chegue a um ponto de entendimento linguístico e cognitivo.

Esse processo tem, de um lado, o sistema de informação com seu entendimento sobre a solicitação do usuário e as ofertas de informação potencialmente capazes de atendê-lo. Do outro, existe o próprio usuário, que precisa compreender o que lhe é oferecido para que se decida a aceitar, ou não, a informação recebida como resposta de solução ao seu problema.

No espaço dos sistemas de informações, a linguagem documentária (como linguagem de mediação) é o instrumento que viabiliza as operações de produção e recepção da informação. Ela faz a conversão dos elementos potencialmente informativos (recortes de sentido, evidências, conceitos, etc.) presentes nos documentos em informação documentária e, do mesmo modo, permite que as perguntas do usuário ao sistema sejam providas. Entretanto, não deve ser encarada como um código limitador, mas como um protocolo dinâmico que, na instância de recepção, possibilite a negociação de sentidos, bem como a sua própria atualização.

Procurando exemplificar, descrevemos uma situação verídica de atendimento. $\mathrm{O}$ procurador jurídico de um município solicitava informações sobre ocupação do espaço público, uma vez que o termo “espaço público", até então, não constava do sistema. No âmbito jurídico, tal designação significa tudo o que não é privado. Um conceito bastante 
genérico que, fora do texto, pode conotar vários sentidos, tais como uso e ocupação do solo, equipamento público, bens públicos, vias e logradouros públicos, etc. Na negociação, percebeu-se que a demanda referia-se à ocupação de bem público para fins comerciais, mais precisamente de "vias e logradouros públicos". O problema do usuário era impedir que os bares utilizassem o espaço das calçadas para colocar suas mesas. Essa enunciação foi produto do diálogo estabelecido entre o usuário e o bibliotecário. Nesse caso, a recuperação da informação desejada não apresentava equivalência com o sistema e dependia da compatibilização do termo utilizado na pergunta (ou do controle dos diferentes contextos de usos da informação) com a linguagem adotada na entrada da informação (codificação). Não existia um parecer indexado no termo exato da busca, mas existiam vários outros, sob os descritores de "vias e logradouros", "bens públicos", "uso comercial", que, cruzados, respondiam à indagação do usuário.

Uma consulta procura responder ao enunciado de uma pergunta, traduzindo uma necessidade objetiva em um problema ou um tema. Temáticas são mais simples de serem tratadas porque são previsíveis, elas se referem aos ramos do direito aplicados à governança e vereança municipal. Já os problemas, não: a qualquer instante podem aparecer questões novas ou mesmo às perguntas reincidentes podem corresponder enunciados variados que exigem uma interpretação e uma tradução antes da realização da busca. Em outras palavras, a linguagem especializada produz representação para os conceitos, formaliza as designações oferecendo referências seguras à comunicação documentária, mas o controle das palavras utilizadas nos enunciados dos problemas, ou melhor, as articulações remissivas realizadas pelo sistema documentário, parecem ser sempre insuficientes. Assim sendo, a dinâmica do atendimento é a maior fonte de atualização da linguagem documentária, principalmente no que se refere à compatibilização entre o contexto de uso da informação, que expressa um problema, e o contexto de produção da informação, que transforma os problemas em representações temáticas específicas. Nesse particular, o uso de remissivas não se adapta apenas ao controle de ambiguidades, mas também ao controle semântico dos termos de menor incidência.

A base de dados não está organizada em termos de perguntas e respostas. Os documentos são processados a partir das respostas, motivo pelo qual os profissionais 
(que atendem e indexam) têm que ter conhecimento e controle do universo contextual ao qual a base se refere, senão a estratégia necessária à recuperação da informação fica impossível de ser estabelecida. Na verdade, a busca depende da combinação das representações providas pela linguagem documentária para reproduzir uma pergunta complexa e sua resposta ou, no mínimo, para dar pistas sobre elas. As buscas são baseadas na probabilidade de resposta, ou seja, em critérios probabilísticos e não deterministas. Para uma solicitação podem ser oferecidas mais de uma resposta/documento.

A Base de Pareceres funciona bem se considerarmos que o índice de recuperações irrelevantes ou de respostas negativas frente à demanda recebida é baixo. $\mathrm{Na}$ nossa avaliação, esse resultado positivo é tributário da experiência institucional acumulada no atendimento da comunidade usuária. O entendimento técnico-jurídico dos problemas municipais, combinado com a experiência de como a incerteza se manifesta nas perguntas do público usuário, são as chaves da prática informacional exercida na instituição como um todo. A linguagem documentária, no seu arcabouço lógicosemântico, procura se apropriar dos elementos oriundos dessa realidade para poder funcionar como instrumento de representação de informações. O repertório de termos e expressões empregados faz parte da cultura da Casa, convertendo-se em elementos da linguagem de recuperação da informação. Publicações produzidas pelo órgão, eventos, apresentações de trabalhos e o próprio exercício do atendimento, promovem a socialização de conhecimentos relacionados à realidade municipal. No caso específico da biblioteca, há ainda a leitura cotidiana da documentação que (in) forma no referente ao universo conceitual e às novas questões. Obviamente, os limites profissionais são claros, entretanto, em alguns pontos, as práticas para transferência da informação se aproximam.

O município, por seu lado, também troca conhecimentos com a convivência estabelecida, ou porque consulta a área jurídica e a biblioteca, ou porque participa dos cursos oferecidos e utiliza os produtos institucionais. Tudo isso faz do Cepam/Municipalidades uma espécie de comunidade. Essa é a dinâmica de organização e de transferência de informação, produto de uma história de muitos anos. 
Com o avanço tecnológico, a dinâmica de gestão da coleção passa por mudanças. Apesar de riscos ainda existentes, os documentos em papel deixam de prevalecer e, assim sendo, o trabalho sofre modificações para privilegiar o formato digital. Para contemplar essa modernização, em nossa opinião, a organização em formato de mapa conceitual, estruturado a partir dos contextos de usos da informação, seria a melhor solução para o acesso, na medida em que proporciona maior interatividade entre os usuários e os documentos. O mundo virtual/digital não dispensa a mediação, ele a exige, só que em um padrão inteligível para sua natureza.

O caminho escolhido pela instituição para divulgação e acesso das informações jurídicas foi o da implementação de um serviço de perguntas e respostas, mobilizando correio eletrônico para o "tira-dúvidas jurídico" e o site para divulgação de pareceres exemplares.

\subsection{O formato de perguntas e respostas na web}

Se a prática que discutimos acima tem por objetivo a organização da coleção do ponto de vista da preservação da memória jurídica da instituição para manipulação e uso, este item procura abordar a estratégia de transformação do estoque em serviço web aberto ao usuário Cepam.

No contexto da comunicação digital, a aplicação destaca o valor utilitário da informação, isto é, o formato de perguntas e respostas condensa o conteúdo anteriormente registrado nos pareceres e permite o acesso direto do usuário às informações (e ao documento em formato digital), adquirindo o caráter de prestação de serviço. A partir de um conjunto de perguntas organizadas por tema e a ementa da resposta, o usuário identifica qual delas mais se aproxima de suas necessidades. Nesse caso, a relação entre a carência de informação (que caracteriza a dúvida do receptor) e o acesso (que caracteriza a resposta institucional) é mediada pelos temas que ordenam os enunciados das perguntas e as ementas das respostas, possibilitando a ação de seleção.

O ideal da prática é determinista, ou seja, para cada pergunta sua resposta objetiva, nos casos especificados, substituir um atendimento face a face. Os textos- 
respostas, frutos de experiências anteriores recorrentes, ampliam e racionalizam o atendimento com base na repetição: dúvidas de complexidade conhecida (já estudadas) podem ser atendidas virtualmente por meio da socialização e/ou transferência da solução encontrada para outros municípios.

A nosso ver, esse formato de transferência da informação tem seu foco na legibilidade dos textos disponibilizados e na inteligibilidade dos temas usados na ordenação dos conjuntos, tendo em vista seus propósitos de mensagem. Nessa dimensão, espera-se que o texto de ordem jurídica que pode responder à inquietação de usuários reais ou potenciais seja condensado nos seus aspectos fundamentais, isto é, que responda a uma questão conceitual ou doutrinária de maneira acessível e/ou que evidencie dispositivos legais envolvidos, remetendo o consulente para os textos das leis e jurisprudências, enfim, que o esclareça sobre a ação inquirida.

A vantagem do formato está no favorecimento da consulta, pois, simulando um diálogo, apresenta: a pergunta, uma resposta objetiva, a análise concisa dos dispositivos legislativo e jurisprudencial que fundamentam a resposta e, como opção complementar de leitura mais profunda, aí sim, um parecer na íntegra funcionando como exemplo. Apresentamos, na figura 10, a simulação do que imaginamos ser uma página ideal. Nela reservamos um ambiente com a estrutura classificatória de acesso, através da qual cada assunto acessado subdivide-se em outros, formando um segundo nível de seleção mais específico, outro de texto para apresentação das perguntas e das respostas correspondentes, marcadas com links que remetem a outros textos, como, por exemplo, o texto de uma lei, um campo de exemplos no qual anexamos textos de pareceres na íntegra sobre o tema e, ainda, um espaço para divulgação de estatísticas relacionadas à utilização do serviço (temas preferenciais, assuntos não pesquisados, órgãos demandantes, municípios usuários, etc.). 
Figura 10 - Simulação de página web para P\&R

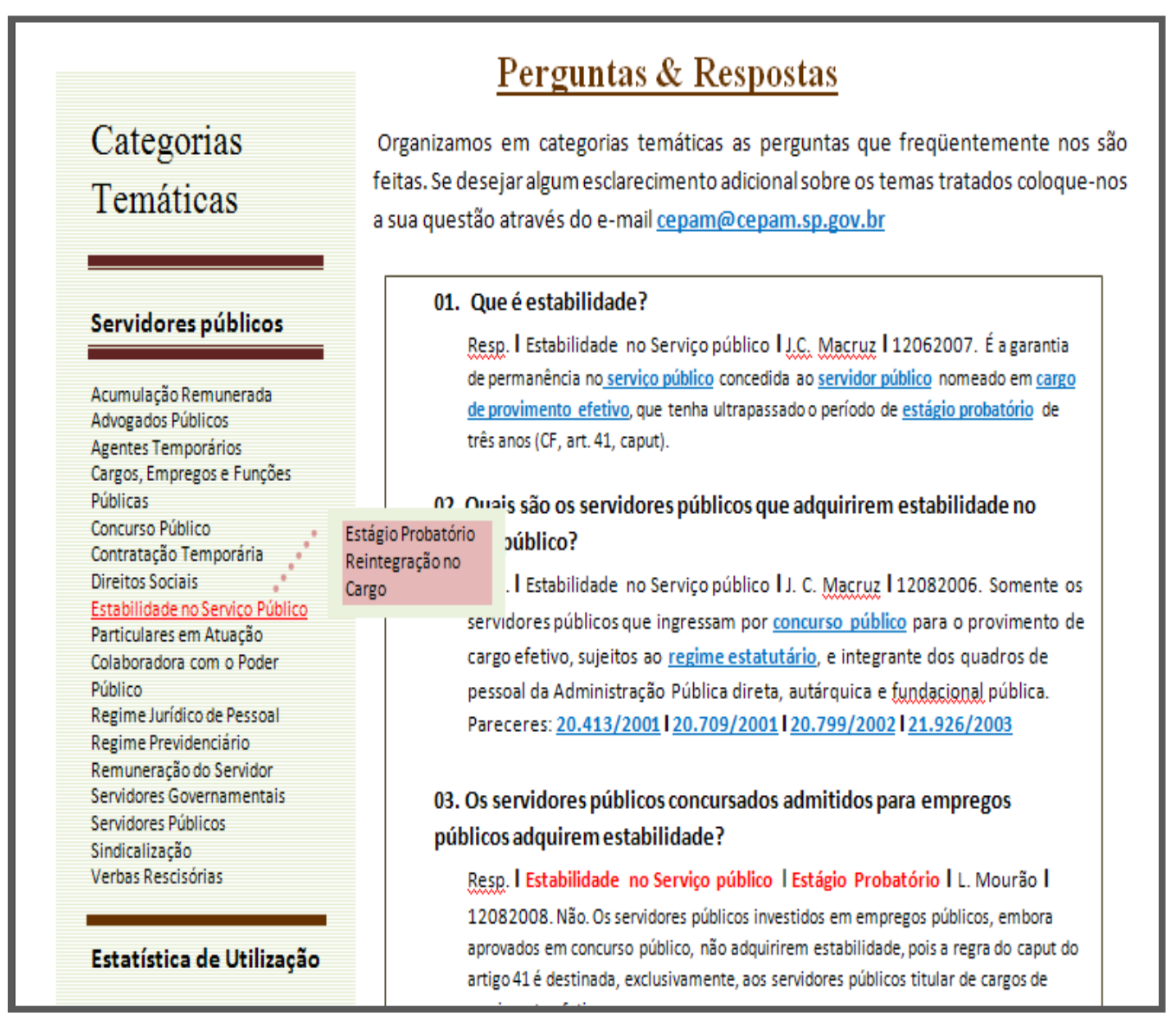

Contudo, é preciso enfatizar que o crescimento do conjunto informativo pode constituir um problema caso o processamento documentário não seja suficiente e adequado para produzir resultados relevantes. A qualidade da linguagem documentária oferecida como esquema lógico de pesquisa na arquitetura da página é equivalente à recuperação conseguida. Temas muito genéricos, encabeçando grande quantidade de perguntas referentes a aspectos particulares, promovem um custo adicional no momento da pesquisa, pois a seleção das informações relevantes torna-se uma tarefa demorada e pouco eficiente. Em outras palavras, grandes quantidades de informação, mesmo que compactadas em formatos mais condensados, dependem da existência de estruturas classificatórias que racionalizem a oferta e o uso no que se refere ao contexto conceitual e aos níveis de profundidade das respostas. Assim sendo, a única forma de representar a informação é organizá-la em “pedaços” manejáveis, ou seja, relacioná-la a campos de significado que sejam úteis aos propósitos do sistema, que pressupõe a relação entre estruturas de registro da informação e os mapas mentais dos usuários. 
Entendemos por mapa mental a memória sociocognitiva e cultural, não a do usuário individual, mas do usuário coletivo ${ }^{9}$. O mapa diz respeito ao contexto do usuário, ao sistema de conceitos, que funciona subjacente aos diferentes tipos de discursos, permitindo a comunicação. Como já comentamos em outras passagens deste trabalho, a linguagem documentária de base terminológica fundamenta-se nessa lógica. Suas unidades (os descritores), para solidificarem seus significados, estabelecem vínculos com uma dada realidade cognitiva e sociocultural através da seleção e da definição dos termos que compõem a terminologia do grupo em questão. Em termos estratégicos, a linguagem documentária relaciona a informação (estruturas de registro, documentos) com determinadas possibilidades de interpretação (campos de uso).

O processo de geração e de transferência da informação decorre de uma proposta institucional instruída pela linguagem documentária. Dado um contexto ou situação determinada, espera-se que a informação (a mensagem documentária gerada) seja suficiente para comunicar aos usuários os sentidos atribuídos pelo sistema para determinado conteúdo ou até outros sentidos não previstos ou não intencionados $a$ priori.

Em síntese, as perguntas e respostas jurídicas na web, além da ordenação temática, podem ser apresentadas por meio de um pequeno trecho ou cabeçalho, a ementa, permitindo que os usuários interajam com a proposta da fonte produtora e selecione a informação que melhor lhe atender. Segundo Koch (2006, p. 26), uma oferta deve consistir em "hipóteses operacionais eficazes sobre a estrutura e o significado de um fragmento de texto", para que o usuário, utilizando sua capacidade de inferência perante uma informação ainda incompleta, possa desencadear uma hipótese de interpretação, gerando informação semântica nova a partir daquela dada em certo contexto. Entretanto, não é qualquer fragmento que pode ser compreendido ou desencadear interpretações. Para que, numa situação concreta de interação, o receptor seja capaz de selecionar a partir do objetivo da fonte, é necessário que ele tenha acesso a uma quantidade de informação adequada (do ponto de vista sintático) e a certas

\footnotetext{
9 Referimo-nos aos integrantes de situações e/ou de grupos sociais específicos que compartilham interesses e linguagens (LARA e TÁLAMO, 2007)
} 
unidades linguísticas que despertem a sua memória cognitiva, a sua capacidade de percepção e de associação semântica. Nesse sentido, deduzimos que resumos generalizantes e termos muito genéricos, amalgamando grande quantidade de informação, são pouco operacionais para a comunicação documentária.

Nessa dimensão, as propostas de organização das perguntas e respostas jurídicas, na instância de produção, têm que levar em consideração as condições de armazenamento, o consumo já fidelizado e, ao mesmo tempo, as novas possibilidades de uso. Os documentos digitalizados, além de serem processados para ter seus conteúdos informativos recuperados, também podem ser gerenciados enquanto coleção digital, isto é, preparados para fornecer também uma série de informações gerenciais indicativas de sua utilização, tempo de permanência, custos, reprodução constante, relevância perante a dúvida, termos mais usados, etc. Trata-se da dimensão administrativa e gerencial, sobreposta ao manejo cognitivo da informação, com o objetivo de acompanhar o aproveitamento do recurso, o seu consumo, tendo em vista agregar valor às futuras atualizações.

\subsection{Outros meios e formatos voltados à difusão e capacitação da gestão}

Como temos enfatizado durante todo o desenvolvimento deste trabalho, a informação a que nos referimos assemelha-se à mensagem, que, para circular entre atores diversos, depende da adesão ao contexto intelectual do usuário, mas também da formatação, isto é, precisa ser organizada de maneira que os usuários reconheçam nelas exemplares de determinadas modalidades ou estruturas capazes de gerar interpretações.

No âmbito da informação pública, as informações podem ser de natureza jurídica, administrativa, estatística, legislativa, jornalística, financeira, técnica, política, etc. Cada uma é estruturada de modo que possa ser identificada, porque estabelece sua diferença e comunicabilidade em relação às demais. Consideramos informação pública aquela gerada e/ou acumulada em razão das atividades do governo e convergente com os interesses ou consumo dos atores envolvidos com a esfera pública, sejam eles servidores públicos, profissionais do governo, agentes políticos ou cidadãos. Entendemos também que o direito à informação pública é historicamente construído 
pelas sociedades democráticas e, nesse sentido, o trabalho documentário, por proporcionar acesso e a circulação, é fundamental. Segundo Jardim e Marcondes (2003)

a informação governamental é um dos principais componentes dos dispositivos de mediação no jogo democrático que envolve Estado e Sociedade Civil. As condições em que é produzida, estocada e disseminada dentro e fora do Estado determinam e são determinadas - direta ou indiretamente - pela diversidade de atores do cenário político-social. Isto pressupõe, no mínimo, que o Estado reconheça a informação como recurso gerencial intrínseco a todas as suas ações e objeto de políticas públicas específicas.

Assim sendo, para cumprir com seus objetivos e serem compreendidas, acessadas ou transferidas, as informações de natureza pública transformam-se (ou são codificadas) em legislação, em gráficos, em diferentes espécies de textos, em quadros sinóticos, em referências bibliográficas, em metadados, em resumos, em hipertexto, dependendo do meio a ser usado e das finalidades de sua divulgação. Os meios são diversos, vão das publicações impressas às acessíveis digitalmente; das bibliotecas e centros de informações tradicionais às bibliotecas digitais, virtuais e aos observatórios; dos arquivos aos repositórios e, ainda, dos portais governamentais às propostas de governos eletrônicos.

A escolha dos meios e dos formatos utilizados para a organização da informação está diretamente relacionada com a modalidade de informação em causa, com os propósitos e disponibilidades institucionais e com as preferências do público usuário. Assim, a diversidade de formatos cobre finalidades de uso e de especialidades. Criam-se formatos para se promover "ações de informação" (CAPURRO, 2003; LARA e TÁLAMO, 2007) e para atingir as dinâmicas de interação. Os especialistas trabalham com o estado da arte, ou seja, com a informação no sentido da geração e organização do conhecimento e, para isso, adotam determinados padrões e meios de transferência, tais como artigos, publicações, palestras e cursos, notícias, pesquisas, etc. Já os documentalistas dedicam-se à organização da informação para fins de divulgação e uso. Nesse universo operam com processos, formatos e meios específicos capazes de promover a condensação necessária à promoção do acesso e à circulação do conhecimento registrado. Conforme Ortega e Lara (2008, p. 6 e p. 8), o processamento documentário tem por objetivo evidenciar "como os objetos tornam-se informativos 
constituindo-se em documentos". Na argumentação das autoras, informação e documentos são categorias relacionadas, pois partimos da análise dos documentos para chegarmos a outros documentos com propósitos informativos e informacionais. Tais documentos são construídos a partir de interesses institucionais, motivados na perspectiva de informar um ponto de vista ou em decorrência de atribuições, quer dizer, a obrigação de tornar pública uma informação, como no caso das esferas governamentais. 


\section{CONCLUSÃO}

mote inicial de elaboração deste trabalho foi a nossa percepção de que, na
sociedade "tecnologizada", a distância que separa um usuário de uma informação desejada é sempre uma distância cognitiva e sociocultural, às vezes fruto da nossa dificuldade em desenhar a comunicação. Essa observação sugere vários caminhos de pesquisa, mas o foco principal de nossa investigação foi o caminho da recepção e da transferência de informações, ou seja, privilegiamos a abordagem da informação como signo linguístico ou, ainda, de outra maneira, procuramos responder como uma mensagem documentária pode transformar-se em informação, uma estrutura reconhecida como útil socialmente.

Nesse contexto, exploramos aspectos estruturais, cognitivos e comunicativos da mensagem documentária, com base na Linguística Documentária, na Terminologia e na Linguística Textual, e consideramos a Fundação Prefeito Faria Lima - Cepam como celeiro das práticas necessárias ao estudo.

Do nosso ponto de vista, e em termos objetivos, as respostas a que chegamos podem ser sintetizadas nos seguintes pontos:

- O que designamos processo de transferência da informação é o estabelecimento de uma dinâmica (fluxo integrativo) entre o sistema informacional e a comunidade usuária. A única maneira de a informação circular socialmente e comunicar idéias é por meio da sua qualificação para acesso e divulgação, isto é, por meio da agregação de valores cognitivos, sociais e pragmáticos que lhe garantam relevância em um determinado contexto de uso de conhecimento. Concordamos com Lara e Tálamo $(2007$, p. 13) que o processo documentário (que prepara a informação para circulação e acesso) distancia-se da proposta da comunicação de massa porque seu eixo estruturante é a criação de fluxos sociais fundados no valor da informação e do conhecimento. Os produtos informacionais são organizados para atender a finalidades específicas de uso da 
informação e essas finalidades nem sempre coincidem com os interesses do público em geral. Assim sendo, a mensagem documentária que entra em fluxo com o receptor qualifica-se, sobretudo, em função de sua capacidade de criar conhecimento e de informar com pertinência sobre determinada questão.

- No âmbito da produção, a informação como signo (estrutura significante) é construída por meio de certa metodologia e pela adoção de certas convenções linguísticas (provenientes das áreas de atividade e do exercício social). Nesse sentido, as terminologias de domínio ou de áreas de atividade e a elaboração dos registros a partir de critérios pragmáticos (da nossa experiência institucional com o grupo usuário expressa em linguagem) fornecem a sustentação necessária para que, numa situação concreta de interação, o receptor seja capaz de compreender o objetivo do emissor e apropriar-se da informação. Enfim, sobre qualquer campo de conhecimento ou de atividade, o papel da Ciência da Informação é lidar com a documentação, definir sentidos, criar filtros, filtrar informações e gerar formatos e padrões específicos (documentos secundários), na perspectiva de operacionalizar as propostas inscritas na política de informação da instituição. Conforme Tálamo e Lara (2007, p. 13) as novas perspectivas da área apontam para a importância do desenvolvimento de filtros sociais mais integrativos, referindo-se à incorporação das características relevantes do usuário à estrutura da mensagem como solução para diminuir o distanciamento (ainda existente) entre as instâncias de produção e de recepção.

- Quando falamos em recuperação de sentidos, a tecnologia empregada faz grande diferença. Muitas das contribuições da pragmática solicitam as tecnologias para serem implantadas. Hoje, existem instrumentos interativos (muitos gratuitos) que podem ser convertidos em apoio ao trabalho documentário. Wiki, por exemplo, é uma ferramenta que, entre outras aplicações, possibilita a construção coletiva de textos ou a indexação colaborativa (como forma de recolher terminologias). Como permite o diálogo, ela pode ser explorada em associação a um sistema documentário para fornecer o contexto dos termos, remeter a uma definição, ou até a um outro texto, com o intuito de explicar sentidos. Mas isso não se resume nas tecnologias. As associações, os complementos ao 
entendimento da informação, são resultado de operações intelectuais que a tecnologia, sozinha, não pode resolver.

- Processamento informacional e tecnologia estão cada vez mais associados e, assim sendo, é imprescindível que haja uma diversidade de formatos de divulgação da informação como meio de encaminhar a interação e o consumo da informação. Sites, blogs, sistemas, redes, vídeos, publicações, etc., são meios utilizados na divulgação e transferência da cultura técnico-científica. Porém, é preciso ressaltar que "os meios possuem uma linguagem própria e, assim sendo, cada qual é aderente a certos tipos de mensagens, não a todas” (LARA, 2009). Reconhecer essa restrição é também uma forma de não confundir informação com tecnologia, ou seja, cada modalidade de informação é posta em circulação a partir de um meio que lhe é propício (adequado).

Acrescentamos, ainda, a estas considerações finais, que a decisão sobre os formatos, meios e instrumentos a serem usados na organização e transferência de informações é uma decisão política que acontece tanto no âmbito das macropolíticas dos governos, quanto no nível específico de todas as instituições. Tendo em vista o regime informacional vigente (que inclui aporte tecnológico), as publicações, as bibliotecas, os sistemas de informação, os portais, os sites, os observatórios, etc., são considerados nós de redes de informação ou elementos de um regime de informação específico. Sabemos que um site não substitui uma conversa institucional entre o Cepam ou outra instituição e um município, entretanto, o serviço de perguntas e respostas, se bem organizado, pode agilizar e diminuir o custo de muitas conversações e, ainda, atender novos públicos. Se as informações divulgadas pelo site forem constantemente atualizadas e seus conteúdos corresponderem às necessidades de pesquisa, elas favorecem os usuários e dão visibilidade e credibilidade à instituição-fonte, posicionando-a em relação aos demais organismos geradores de informação no mesmo campo temático. Em outras palavras, a política informacional não é algo preestabelecido, antes é o exercício das relações de saber e de poder em torno da produção de informações. A estabilidade dos organismos é relativa e dependente do grau de aceitação e de compartilhamento que a informação oferecida consegue conquistar junto aos usuários e, também, junto aos seus pares. 
Grosso modo, quem tem o controle dos meios de produção, portanto, acesso maior à tecnologia, tem mais chance de comandar os processos de organização, armazenamento e distribuição e, ainda, de absorver a produção paralela, ampliando o seu poder de influência. Assim sendo, a informação não existe hoje longe da tecnologia. A capacidade tecnológica das instâncias governamentais ainda deixa a desejar e, para superar esse fator, as instituições, a despeito das soluções tecnológicas mais avançadas, utilizam as parcerias, a criatividade e a elaboração de formatos que podem ser implementados com o apoio de tecnologia trivial.

Nesse contexto, o Estado de São Paulo institui a Política de Gestão do Conhecimento e Inovação para todos os órgãos públicos estaduais, em um esforço pioneiro para melhorar a qualidade da prestação de serviços e valorizar os servidores públicos. Nesse contexto, cria a Rede Paulista de Inovação em Governo, voltada para o uso das ferramentas interativas:

um ambiente onde os funcionários do Governo de São Paulo podem compartilhar experiências inovadoras, voltadas para a melhoria da gestão pública e aprimoramento dos serviços prestados à população. Além de conhecer as experiências de seus colegas, você mesmo pode colaborar com a rede, pois o conteúdo aqui é produzido voluntariamente pelos próprios funcionários do governo. Você poderá se tornar mais um ponto da rede, integrando a ela um veículo próprio de compartilhamento de experiências, como por exemplo, um blog, um canal de vídeos ou de áudio, um sítio. Se ainda não sabe como construir esses canais, nossos tutoriais oferecerão orientações sobre ferramentas e programas gratuitos ou de custo simbólico, que hoje já permitem que todos possam se tornar protagonistas da internet, criando conteúdo e não apenas consultando-o. Disponível em: $<$ http://www.igovsp.net/> Acesso em: 15 de junho de 2008.

O suporte oferecido é viabilizado por meio de quatro blogs (iGovSP, iGovBR, iGovSaber e iGov explica - tutorial), cursos e assessorias, tendo por base a divulgação e a instrução para o uso das ferramentas web 2.0.

Contudo, a despeito da iniciativa que consideramos louvável, ressaltamos, mais uma vez, que cada mensagem pressupõe um meio e que, no âmbito documentário, o simples uso de tais ferramentas não resolve as complexas relações que envolvem a emissão e recepção de informações. A experiência de construção de interatividade a que 
nos referimos pressupõe tecnologia, mas, sobretudo, a experiência institucional com a linguagem do grupo de atividade, não focada em indivíduos isolados, mas no grupo social. A mobilização da rede social em torno do funcionamento interativo dos sistemas documentários depende em grande parte do histórico institucional. As redes sociais existem antes da chegada das tecnologias, que, é certo, as ampliam e as intensificam.

O Cepam tem história para funcionar como filtro de informações para os municípios. Mais do que no sentido de seleção, no sentido de transformar informações complexas em mensagens assimiláveis. Dentro desta perspectiva, produz informação, edita e publica, desenvolve produtos e serviços procurando aderência junto ao seu público preferencial. Com foco no usuário, processa o conhecimento mobilizando competências multidisciplinares e habilidades diversas. Operacionalmente, metodologias específicas são aplicadas à organização da informação. Os procedimentos documentários, isto é, a seleção, a indexação, o resumo e a linguagem documentária estão presentes em muitas iniciativas que envolvem a organização, o acesso e a divulgação de informações, não sendo encarados como prática restrita às bibliotecas. Em outras palavras, a construção dos novos meios de divulgação de conhecimentos e de informações para as finalidades a que nos referimos acima encampa as práticas desenvolvidas pelos sistemas bibliotecários, reeditadas em padrões coerentes com a natureza tecnológica e exigências do meio.

Finalmente, o que observamos neste estudo nos leva a concluir que a inovação no campo da informação pressupõe uma abertura para o desenvolvimento de experiências com linguagens, formatos, padrões e meios, fluxos informativos, estratégias de difusão e tecnologia, sempre no sentido da busca de interação com a comunidade usuária para divulgação do conhecimento, e em concernência com as bases seguras propostas pela Documentação.

Acreditamos que a troca entre sistema e usuários, no sentido da criação de instrumental que possibilite o acompanhamento dos usos dados à informação oferecida, realimenta as propostas instititucionais (os sentidos atribuídos) ou, de outro modo, a oferta. 


\section{REFERÊNCIAS BIBLIOGRÁFICAS}

ARAUJO, E. A.. Informação, sociedade e cidadania: gestão da informação no contexto de organizações não governamentais (ONGs) brasileiras. Ciência da Informação, v. 28, n.2, p. 155-167, mai./ago. $1999 . \quad$ Disponível em: http://www.uel.br/revistas/uel/index.php/informacao/article/view/1683> Acesso em: 12 de abril de 2008 .

BARRETO, A. A. A condição da informação. São Paulo em perspectiva, São Paulo, v.16, n. 3, p. 67-74, jul./set, 2002. Disponível em: 〈http://www.scielo.br/pdf/spp/v16n3/13563.pdf> Acesso em: 15 de fevereiro de 2008.

BARRETO, A. A. A eficiência técnica e econômica e a viabilidade de produtos e serviços de informação. Ciência da informação, v.25, n.3, p. 405-414, 1996. Disponível em: < http://dici.ibict.br/archive/00000176/> Acesso em: 14 de abril de 2009.

BARRETO, A. A. A questão da informação. São Paulo em Perspectiva, Fundação Seade, v. 8, n. 4, p. 3-8, 1994. Disponível em: <http://aldoibct.bighost.com.br/quest/quest2.pdf> Acesso em: 10 de fevereiro de 2008.

BRIET, Suzanne. Qu'est-ce que la documentation? Paris: Edit, 1951.

BUCKLAND, M. K. Information as thing. Journal of the American Society for Information Science, v.45, n.5, p.351-360, june 1991

BUCKLAND, M. K. What is a "document"? Journal of the American Society for Information Science, v.48, n. 9, p. 804-809, 1997.

CABRÉ, M. T. La terminologia hoy: concepciones, tendencias y aplicaciones. Ciência da Informação, v. 24, n. 3, 1995.

CAMARGO, J. C. de C. A disseminação de informações estatísticas na web: da difusão à divulgação. São Paulo: J. C. C. Camargo, 2006. 128 p. il. (Dissertação de mestrado).

CAPURRO, R. Epistemologia e ciência da informação. Anais do V Encontro Nacional de Pesquisa em Ciência da Informação: informação, conhecimento e transdisciplinaridade. Belo Horizonte, 10-14 de nov. 2003. Disponível em: <http://www.capurro.de/enancib_p.htm > Acesso em: 10 de março de 2008 
CAPURRO, R. \& HJØRland, B. O conceito de informação. Perspectivas em Ciência da Informação, v.12, n.1, 2007. Disponível em: <http://www.eci.ufmg.br/pcionline/> Acesso em: 20 de fevereiro de 2008

CASTELLS, M. A sociedade em rede - A era da informação: economia, sociedade e cultura; v. 1. São Paulo: Paz e Terra, 1999.

GARDIN, J. C. Para uma remodelagem das publicações savantes [científicas]: suas relações com as ciências da informação. $3^{\text {ème }}$ coloque d'ISKO-France, Paris, Université de Nanterre - Paris X, 5-6 juillet 2001. Filtrage et résumé automatique de l'information sur les réseaux. (Conferência proferida por convite).

INGWERSEN, P. Information retrieval interaction. London: Taylor Graham, 1992.

GONZÁLES DE GÓMEZ, M. N. Novos cenários políticos para a informação. Ciência da Informação, Brasília, v. 31, n. 1, p. 27-40, jan./abr. 2002. Disponível em: <http://dici.ibict.br/archive/00000213/01/Ci\%5B1\%5D.Inf-2004-582.pdf>. Acesso em: fevereiro de 2008.

JARDIM, J. M.; MARCONDES, C. H. Políticas de Informação Governamental: a construção de Governo Eletrônico na Administração Federal do Brasil. DataGramaZero - Revista de Ciência da Informação, v.4, n.2, abr. 2003. Disponível em: http://www.dgz.org.br/abr03/Art_04.htm. Acesso em: 21 de abril de 2009.

KOBASHI, N. Y. A Elaboração de informações documentárias: em busca de uma metodologia. São Paulo, 1994. 195 p. Tese (Doutorado em Ciência da Comunicação - Escola de Comunicação e Artes, Universidade de São Paulo).

KOBASHI, N. Y.; TÁLAMO, M. F. G. M. Informação: fenômeno e objeto de estudo da sociedade contemporânea. Transinformação, v.15 (ed, especial), p.7-21, set/dez., 2003. Disponível em: <http://revistas.puc-campinas.edu.br/transinfo/viewissue.php?id=5>. Acesso em: 12 de fevereiro de 2008

KOCH, I. G. V.. Introdução à linguística textual. São Paulo: Martins Fontes, 2006. 190p.

LARA, M. L. G. de A representação documentária: em jogo a significação. São Paulo, 1993. Dissertação (Mestrado em Ciências da Comunicação - Escola de Comunicação e Artes, Universidade de São Paulo).

LARA, M. L. G. de. Representação e linguagens documentárias: bases teórico-metodológicas. São Paulo, 1999. Tese (Doutorado em Ciências da Comunicação - Escola de Comunicação e Artes, Universidade de São Paulo). 
LARA, M. L. G. de. A Terminologia (e as terminologias) e a Documentação. In: Simpósio de RITerm,7, Lisboa, 14 a 17 de Nov. de 2000. Atas de 1988-2002. Disponível em: $<$ http://www.riterm.net/actes/7simposio/lara.htm> Acesso em: 26 de novembro de 2007.

LARA, M. L. G. de. Novas relações entre terminologia e Ciência da Informação na perspectiva de um conceito contemporâneo da informação. Datagramazero, Revista de Ciência da Informação, v.7, n.4, ago 2006. Disponível em: 〈http://www.dgz.org.br/ago06/Art 02.htm>. Acesso em: 21 de fevereiro de 2008.

LARA, M. L. G. de. É possível falar em signo e semiose documentária? Enc. Bibli: R. Eletr. Bibliotecon. Ci. Inf., Florianópolis, $2^{\circ}$ número esp., $2^{\circ}$ sem. 2006(A). Disponível em: < http://encontros-bibli-blog.blogspot.com/> Acesso em: 03 de julho de 2008

LARA, M. L. G. de. Informação, informatividade e linguística documentária: paralelos com as reflexões de Hjorland e Capurro. In: Anais do ENANCIB, 8, Salvador, out. 2007. Disponível em: <http://extralibris.org/2007/12/informacao-informatividade-e-linguistica-documentariaparalelos-com-as-reflexoes-de-hjorland-e-capurro/> Acesso em: 15 de fevereiro de 2008.

LARA, M. L. G. de; TÁLAMO, M. de F. G. M. La réception dans les procès documentaire: information et production de sens. In: Actes du $6^{\text {ème }}$ Colloque International du Chapitre Français de l'ISKO, 2007, Toulouse: Organisation des connaissances et société des savoirs: concepts, usages, acteurs. Toulouse: LERASS - Université Paul Sabatier; ISKO, 2007. v. 6. p. 79-95. Disponível em português em: < http://www.rumores.usp.br/lara.pdf> Acesso em: 15 de junho de 2009.

LE COADIC, Y. F. A ciência da informação. Brasília: Briquet de Lemos, 1996.

LIMA, V. M. A. Da classificação do conhecimento científico aos sistemas de recuperação de informação: enunciação de codificação e enunciação de decodificação da informação documentária. São Paulo, 2004. Tese (Doutorado em Ciência da Informação - Escola de Comunicação e Artes, Universidade de São Paulo)

LOPES, E. A identidade e a diferença. São Paulo: Edusp, 1997.

LOPES, E. Fundamentos da linguística contemporânea. São Paulo: Cultrix, 1984.

MACHADO, R. Foucault, a ciência e o saber. $3^{\text {a }}$ ed. rev. e ampliada. Rio de Janeiro: Zahar, 2006.

ORTEGA, C. D.; LARA, M. L. G. de. Documento e informação, conceitos necessariamente relacionados no âmbito da Ciência da Informação. In: Anais do ENANCIB, 9, São Paulo, ago. 2008. Disponível em: < http:// www.enancib2008.com.br/> Acesso em: 02 de janeiro de 2009. 
ORTEGA, C.D. \& LARA, M.L.G. A noção de documento: de Otlet aos dias de hoje. In: Actas del IX Congreso ISKO - España, Valencia, 11-13 mar. Valencia: Universidad Politécnica de Valencia, 2009, p.528-544, t.1.

REALE JR, M. O gosto do mal e o mau gosto. Jornal O Estado de São Paulo, 02 de fevereiro de 2008, Espaço aberto.

RODRÍGUEZ BRAVO, B. El documento: entre la tradición y la renovación. Gijón: Ed. Trea, 2002.

SANTOS, B. de S. Introdução a uma ciência pós-moderna. Rio de Janeiro: Graal, 1989.

SARACEVIC, T. Ciência da informação: origem, evolução e relações. Perspectiva em Ciência da Informação, Belo Horizonte, v. 1, n. 1, p. 41-62, jan./jun. 1996.

SAUSSURE, F. Curso de linguística geral. São Paulo: Cultrix; Edusp, 1969.

TÁLAMO, M. F. G. M. e outros. A interface, análise documentária, linguística documental e terminologia, Madri, $3^{\circ}$ RITERM, 1992, resumo.

TÁLAMO, M. F. G. M. Linguagem documentária. São Paulo: Associação Paulista de Bibliotecários, 1997. (Ensaios APB, 45).

TÁlAMO, M. F. G. M. Terminologia e Documentação. Tradterm Revista do Centro Interdepartamental de Tradução e Terminologia/ Faculdade de Filosofia, Letras e Ciências Humanas da Universidade de São Paulo, São Paulo: Humanitas, n.7, p.141-152, 2001.

TÁLAMO, M. F. G. M.; SMIT, J. W. (2007) Ciência da informação: pensamento informacional e integração disciplinar. Brazilian Journal of Information Science, v. 1, n. 1, jan/jun. p. 3357. Disponível em: 〈http://revista.ibict.br/pbcib/index.php/pbcib/article/view/745> $<$ www.bjis.unesp.br/pt/include/getdoc.php?id=47\&article=8\&mode=pdf $>$ Acesso em: 20 de janeiro de 2009.

VOGT, C. A Espiral da cultura científica. 2003. Disponível em: $<$ http://www.comciencia.br/reportagens/cultura/cultura01.shtml > Acesso em: 14 de março de 2008 .

VOGT, C. Percepção pública da ciência: uma revisão metodológica e resultados para São Paulo. In: Indicadores de ciência, tecnologia e inovação em São Paulo. São Paulo: Fapesp, 2005. Disponível em: 〈www.fapesp.br/indicadores2004/volume1/cap12 vol1.pdf> Acesso em: 02 de julho de 2008. 